\title{
Cholinesterase inhibitors for dementia with Lewy bodies, Parkinson's disease dementia and cognitive impairment in Parkinson's disease (Review)
}

\author{
Rolinski M, Fox C, Maidment I, McShane R
}

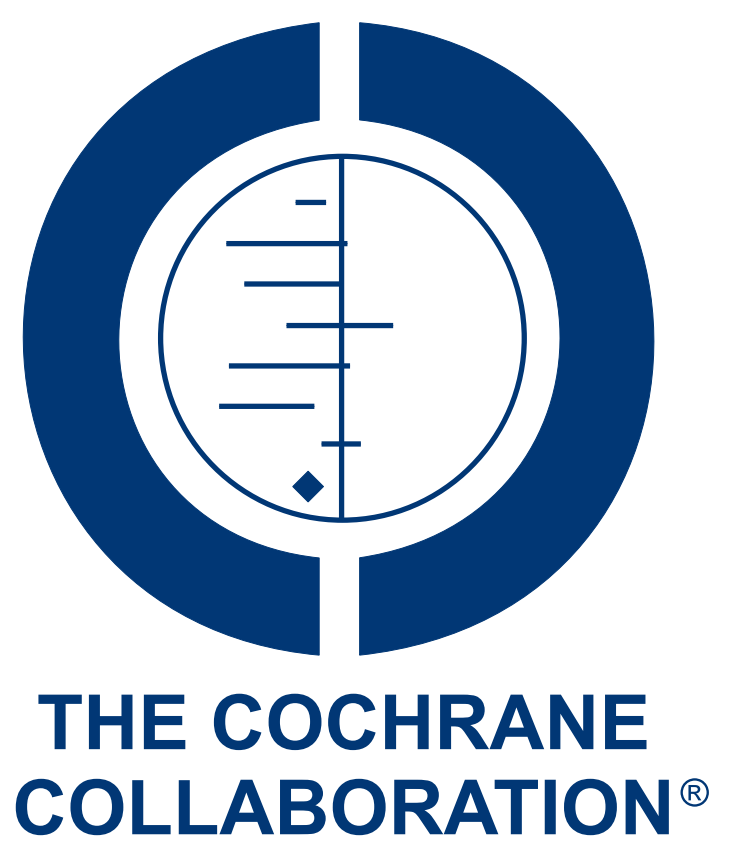

This is a reprint of a Cochrane review, prepared and maintained by The Cochrane Collaboration and published in The Cochrane Library 2012, Issue 3

http://www.thecochranelibrary.com

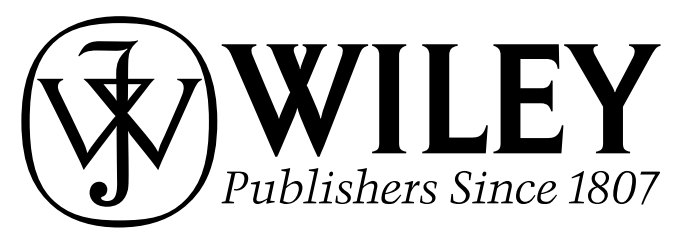

Cholinesterase inhibitors for dementia with Lewy bodies, Parkinson's disease dementia and cognitive impairment in Parkinson's disease (Review)

Copyright () 2012 The Cochrane Collaboration. Published by John Wiley \& Sons, Ltd. 
TABLE OF CONTENTS

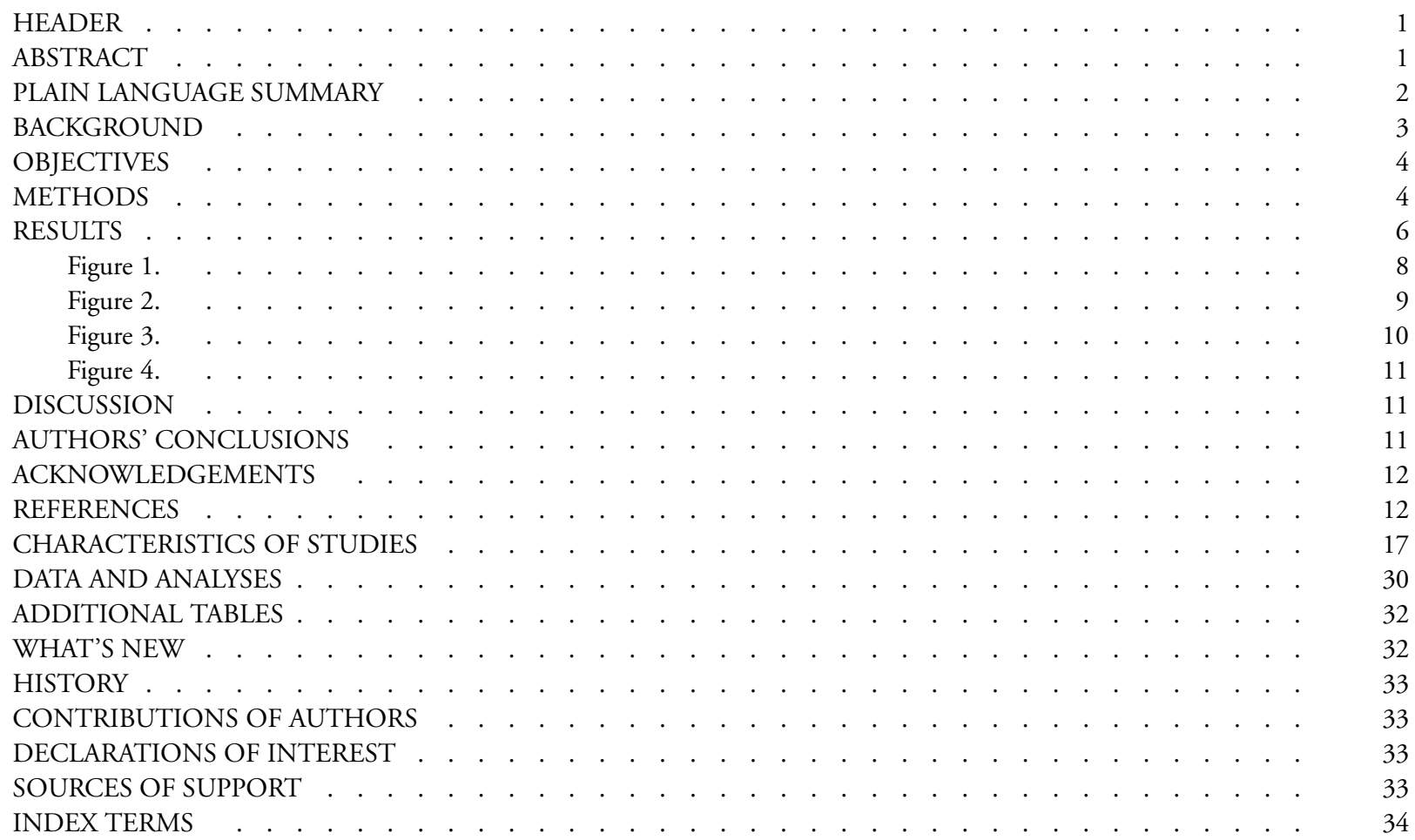

Cholinesterase inhibitors for dementia with Lewy bodies, Parkinson's disease dementia and cognitive impairment in Parkinson's disease (Review)

Copyright () 2012 The Cochrane Collaboration. Published by John Wiley \& Sons, Ltd. 


\title{
[Intervention Review]
}

\section{Cholinesterase inhibitors for dementia with Lewy bodies, Parkinson's disease dementia and cognitive impairment in Parkinson's disease}

\author{
Michal Rolinski ${ }^{1}$, Chris Fox ${ }^{2}$, Ian Maidment ${ }^{3}$, Rupert McShane ${ }^{4}$ \\ ${ }^{1}$ Oxford University Hospitals NHS Trust, Oxford, UK. ${ }^{2}$ Norwich Medical School, Norwich, UK. ${ }^{3}$ Pharmacy Department, Kent and \\ Medway NHS and Social Care Partnership Trust, Canterbury, UK. ${ }^{4}$ Nuffield Department of Medicine, University of Oxford, Oxford, \\ UK
}

Contact address: Michal Rolinski, Oxford University Hospitals NHS Trust, John Radcliffe Hospital, Headington, Oxford, OX3 9DU, UK. michal.rolinski@doctors.org.uk.

Editorial group: Cochrane Dementia and Cognitive Improvement Group.

Publication status and date: New, published in Issue 3, 2012.

Review content assessed as up-to-date: 30 August 2011.

Citation: Rolinski M, Fox C, Maidment I, McShane R. Cholinesterase inhibitors for dementia with Lewy bodies, Parkinson's disease dementia and cognitive impairment in Parkinson's disease. Cochrane Database of Systematic Reviews 2012, Issue 3. Art. No.: CD006504. DOI: $10.1002 / 14651858 . C D 006504 . p u b 2$.

Copyright (C) 2012 The Cochrane Collaboration. Published by John Wiley \& Sons, Ltd.

\section{A B S T R A C T}

\section{Background}

Previous Cochrane reviews have considered the use of cholinesterase inhibitors in both Parkinson's disease with dementia (PDD) and dementia with Lewy bodies (DLB). The clinical features of DLB and PDD have much in common and are distinguished primarily on the basis of whether or not parkinsonism precedes dementia by more than a year. Patients with both conditions have particularly severe deficits in cortical levels of the neurotransmitter acetylcholine. Therefore, blocking its breakdown using cholinesterase inhibitors may lead to clinical improvement.

\section{Objectives}

To assess the efficacy, safety and tolerability of cholinesterase inhibitors in dementia with Lewy bodies (DLB), Parkinson's disease with dementia (PDD), and cognitive impairment in Parkinson's disease falling short of dementia (CIND-PD) (considered as separate phenomena and also grouped together as Lewy body disease).

\section{Search methods}

The trials were identified from a search of ALOIS, the Specialised Register of the Cochrane Dementia and Cognitive Improvement Group (on 30 August 2011) using the search terms Lewy, Parkinson, PDD, DLB, LBD. This register consists of records from major healthcare databases (MEDLINE, EMBASE, PsycINFO, CINAHL) and many ongoing trial databases and is updated regularly.

Reference lists of relevant studies were searched for additional trials.

\section{Selection criteria}

Randomised, double-blind, placebo-controlled trials assessing the efficacy of treatment with cholinesterase inhibitors in DLB, PDD and cognitive impairment in Parkinson's disease (CIND-PD).

Cholinesterase inhibitors for dementia with Lewy bodies, Parkinson's disease dementia and cognitive impairment in Parkinson's disease (Review)

Copyright ( 2012 The Cochrane Collaboration. Published by John Wiley \& Sons, Ltd. 


\section{Data collection and analysis}

Data were extracted from published reports by one review author (MR). The data for each 'condition' (that is DLB, PDD or CINDPD) were considered separately and, where possible, also pooled together. Statistical analysis was conducted using Review Manager version 5.0 .

\section{Main results}

Six trials met the inclusion criteria for this review, in which a total of 1236 participants were randomised. Four of the trials were of a parallel group design and two cross-over trials were included. Four of the trials included participants with a diagnosis of Parkinson's disease with dementia (Aarsland 2002a; Dubois 2007; Emre 2004; Ravina 2005), of which Dubois 2007 remains unpublished. Leroi 2004 included patients with cognitive impairment and Parkinson's disease (both with and without dementia). Patients with dementia with Lewy bodies (DLB) were included in only one of the trials (McKeith 2000).

For global assessment, three trials comparing cholinesterase inhibitor treatment to placebo in PDD (Aarsland 2002a; Emre 2004; Ravina 2005) reported a difference in the Alzheimer's Disease Cooperative Study-Clinical Global Impression of Change (ADCS-CGIC) score of -0.38 , favouring the cholinesterase inhibitors (95\% CI -0.56 to $-0.24, \mathrm{P}<0.0001)$.

For cognitive function, a pooled estimate of the effect of cholinesterase inhibitors on cognitive function measures was consistent with the presence of a therapeutic benefit (standardised mean difference (SMD) $-0.34,95 \%$ CI -0.46 to $-0.23, \mathrm{P}<0.00001$ ). There was evidence of a positive effect of cholinesterase inhibitors on the Mini-Mental State Examination (MMSE) in patients with PDD (WMD $1.09,95 \%$ CI 0.45 to $1.73, \mathrm{P}=0.0008$ ) and in the single PDD and CIND-PD trial (WMD $1.05,95 \%$ CI 0.42 to $1.68, \mathrm{P}=0.01$ ) but not in the single DLB trial.

For behavioural disturbance, analysis of the pooled continuous data relating to behavioural disturbance rating scales favoured treatment with cholinesterase inhibitors (SMD -0.20, 95\% CI -0.36 to $-0.04, \mathrm{P}=0.01$ ).

For activities of daily living, combined data for the ADCS and the Unified Parkinson's Disease Rating Scale (UPDRS) activities of daily living rating scales favoured treatment with cholinesterase inhibitors (SMD $-0.20,95 \% \mathrm{CI}-0.38$ to $-0.02, \mathrm{P}=0.03$ ).

For safety and tolerability, those taking a cholinesterase inhibitor were more likely to experience an adverse event (318/452 versus 668/ 842; odds ratio $(\mathrm{OR}) 1.64,95 \% \mathrm{CI} 1.26$ to $2.15, \mathrm{P}=0.0003)$ and to drop out $(128 / 465$ versus $45 / 279$; OR $1.94,95 \%$ CI 1.33 to $2.84, \mathrm{P}=0.0006)$. Adverse events were more common amongst those taking rivastigmine (357/421 versus $173 / 240 ;$ OR $2.28,95 \%$ CI 1.53 to $3.38, \mathrm{P}<0.0001$ ) but not those taking donepezil (311/421 versus $145 / 212$; OR $1.24,95 \%$ CI 0.86 to $1.80, \mathrm{P}=0.25$ ). Parkinsonian symptoms in particular tremor (64/739 versus 12/352; OR 2.71, 95\% CI 1.44 to 5.09, $\mathrm{P}=0.002)$, but not falls ( $\mathrm{P}=$ 0.39), were reported more commonly in the treatment group but this did not have a significant impact on the UPDRS (total and motor) scores $(\mathrm{P}=0.71)$. Fewer deaths occurred in the treatment group than in the placebo group $(4 / 465$ versus $9 / 279 ;$ OR $0.28,95 \%$ CI 0.09 to $0.84, \mathrm{P}=0.03)$.

\section{Authors' conclusions}

The currently available evidence supports the use of cholinesterase inhibitors in patients with PDD, with a positive impact on global assessment, cognitive function, behavioural disturbance and activities of daily living rating scales. The effect in DLB remains unclear. There is no current disaggregated evidence to support their use in CIND-PD.

\section{PLAIN LANGUAGE SUMMARY}

\section{Cholinesterase inhibitors are beneficial for people with Parkinson's disease and dementia}

The clinical features of dementia with Lewy bodies (DLB) and Parkinson's disease with dementia (PDD) have much in common. As patients with DLB and PDD have particularly severe deficits in cortical levels of the neurotransmitter acetylcholine, blocking its breakdown using a group of chemicals known as cholinesterase inhibitors may lead to clinical improvement. Six trials showed a statistically significant improvement in global assessment, cognitive function, behavioural disturbance and activities of daily living rating scales in PDD and cognitive impairment in Parkinson's disease (CIND-PD) patients treated with cholinesterase inhibitors. There was no current disaggregated evidence to support their use in CIND-PD. No statistically significant improvement was observed in patients with DLB treated with cholinesterase inhibitors and further trials are necessary to clarify the effect of cholinesterase inhibitors in this patient group. 


\section{B A C K G R O U N D}

'When you've seen one patient with dementia, you've seen one patient with dementia'. This commonplace observation about the wide heterogeneity in the clinical presentation of dementia raises the possibility that there may be useful diagnostic subdivisions. The most common cause of dementia is Alzheimer's disease but there are several others, of which dementia with Lewy bodies is arguably the second most common.

Lewy bodies are the defining pathological feature of idiopathic Parkinson's disease. These inclusion bodies are found in the cytoplasm of cells of a wide variety of subcortical nuclei, including those of monoaminergic neurons. They are more likely to occur in cortical neurons in patients with Parkinson's disease when the patients also have dementia. A defining constituent is fibrillar aggregates of alpha-synuclein, a presynaptic protein involved in vesicle formation (Lee 2006). One current theory about why Lewy bodies form is that the cellular mechanisms for degrading and disposing of intracellular protein fragments (proteasomes) are dysfunctional (Olanow 2006). In epidemiological studies, up to $30 \%$ of those people with dementia have Lewy bodies (Zaccai 2005). The rate of dementia in clinical Parkinson's disease (24\% to 31\%) (Aarsland 2005) is at least two to five times that expected in age matched controls. Longitudinal studies suggest that most patients with Parkinson's disease who survive will eventually develop dementia (Aarsland 2003).

\section{Scope of this review}

Previous Cochrane reviews have considered the use of cholinesterase inhibitors in both Parkinson's disease with dementia (PDD) (Maidment 2006) and dementia with Lewy bodies (DLB) (Wild 2003). The clinical features of DLB and PDD have much in common. There is some convergence of opinion that DLB and PDD may be the same condition, but the matter is not fully resolved because DLB and PDD have slightly different neuropathological correlates (Ballard 2006; Burn 2006; McKeith 2005).

The diagnosis of PDD rests on the occurrence of formally diagnosed Parkinson's disease followed at least 12 months later by dementia (with no other apparent cause identified). Most patients with Parkinson's disease have at least subtle deficits in neuropsychological function, typically affecting visuospatial and sometimes executive function. In many cases this does not cause problems and is only apparent on detailed specialist evaluation. Cognitive impairment that is clinically significant typically involves more clearcut deficits in these areas but also tends to affect attention. These are also the three areas of function (visuospatial, executive, attention) prominently affected early in patients labelled DLB. Memory function may be affected late in the process. Dementia is more likely to occur in those in whom the Parkinson's disease develops later, tends to be of the postural instability-gait disorder subtype and to be associated with visual hallucinations when treated with L-dopamine (L-DOPA). The development of dementia associated with Parkinson's disease increases caregiver distress, nursing home requirements and mortality, twofold. It also reduces quality of life (Bedard 2003; Burn 2003). Similarly, parkinsonism in Alzheimer's disease increases the cost of care (Bostrom 2006).

The formal distinction between PDD and early cognitive impairment in Parkinson's disease rests on the definition of dementia. Dementia is defined as occurring when cognitive impairment is of a severity or type such that it interferes with day-to-day occupational and social functioning. However, it is particularly difficult to judge reliably whether any impairment in function in Parkinson's disease is due to cognitive decline or alternatively to the motor, mood or personality changes which may occur. In this review, we have therefore also included a further group of patients, patients who have Parkinson's disease and who have clinically significant cognitive impairment but in whom the diagnosis of dementia has not been formally established. This is analogous to the 'Cognitive Impairment, Not Dementia (CIND)' category and will be termed 'CIND-PD'. This approach is consistent with the current version of the Diagnostic and Statistical Manual of Mental Disorders (DSM-IV-R) criteria (294.1x).

The diagnosis of 'probable DLB' is more complex than that for PDD. It depends on the presence of two of: persistent visual hallucinations; fluctuations in cognitive and functional ability; and parkinsonism. If parkinsonian symptoms are part of the picture, dementia should have occurred within 12 months of the onset of the parkinsonian symptoms. Additionally, 'probable DLB' can also be diagnosed if just one of these original features is present plus one of the following: severe sensitivity to neuroleptics; rapid eye movement (REM) sleep behaviour disorder; or evidence of striatal dopamine transporter protein loss on neuroimaging (McKeith 2005).

Other symptoms that support the diagnosis but are of less clearcut diagnostic value are repeated falls, syncope, transient disturbances of consciousness, severe autonomic dysfunction (for example orthostatic hypotension), urinary incontinence, systematised delusions, non-visual hallucinations, depression, relative preservation of medial temporal lobe structures on a computed tomography (CT) or magnetic resonance imaging (MRI) scan, generalized low uptake on single-photon emission CT (SPECT) or positron emission tomography (PET) perfusion scan with reduced occipital activity, abnormal (low uptake) [123I] meta-iodobenzylguanidine (MIBG) myocardial scintigraphy and prominent slow wave activity on electroencephalography (EEG) with temporal lobe transient sharp waves. Olfactory function may also be impaired (Williams 2009).

The distinction between PDD and DLB was introduced in 1995 ( McKeith 1996). It was recognised at the time that these conditions had much in common, and that the cut-off period of 12 months was arbitrary. The distinction was in part driven by the fact that, in some health systems, patients who develop Parkinson's disease first tend to see neurologists whereas those who develop cognitive impairment first tend to see psychiatrists. It also reflected in the fact that regulators can only issue licenses for drugs where a claim is 
made for the drug in a clearly defined (and accepted) condition. In the third revision of the consensus statement (McKeith 2005), the DLB consortium has suggested that a generic term such as Lewy body disease (LB disease) may be helpful when PDD and DLB are considered together, but that in clinical situations the terms PDD and DLB should be retained as they differentiate between whether symptoms of dementia occur before or after those of Parkinson's disease.

By considering the results of treatment trials for PDD, DLB and CIND-PD, both separately and together, it may be possible to see whether there is any difference in the response to cholinesterase inhibitors in these conditions.

\section{Rationale for cholinesterase inhibitors}

Lewy bodies occur in the dopamine-producing cells of the substantia nigra, where their presence is associated with the movement problems of Parkinson's disease. However, alpha-synuclein aggregation occurs in many other brain areas too and the extent of this may correlate with dementia (Braak 2006). A broad correlation can also be made between the areas affected and specific clinical symptoms: cholinergic deficits and attention or memory (Nakano 1984); serotonergic deficits and depression (Jellinger 1994); dopaminergic deficits and visuospatial or executive symptoms (Dubois 1997); and cortical LBs and executive function impairment. In his original description, Frederick Lewy actually put more emphasis on the occurrence of LBs in the large cells of the substantia innominata (now named the nucleus basalis of Myenert). We now know that these cells synthesise acetylcholine and project widely to cortical areas. This nucleus is also affected by the neurofibrillary tangles of Alzheimer's disease. Patients with DLB or PDD have particularly severe deficits in cortical levels of acetylcholine and its enzyme for synthesis, even exceeding the deficits of patients with just Alzheimer's disease (AD) pathology (Perry 1994). The key neuropathological defect that is targeted by cholinesterase inhibitors is therefore present in AD, PDD and DLB. Moreover, the lower cholinergic functioning in DLB and PDD may indicate a greater potential improvement from these drugs than that seen in AD. Since there are fewer neurofibrillary tangles and neuritic plaques and less neuronal loss in DLB than AD (Lippa 1998), it is possible that cortical neurons in DLB are more viable than those in $\mathrm{AD}$ and could be more responsive to cholinergic stimulation. Similarly, because those patients with visual hallucinations and more profound deficits in attention tend to have worse cholinergic deficits, the presence of this symptom may be a predictor of treatment response.

The combination of psychotic features and parkinsonism which occur in DLB and PDD can be particularly difficult to manage. Antipsychotic drugs used to treat hallucinations, delusions and agitation can dramatically worsen cognitive and extrapyramidal symptoms and may lead to severe, and even fatal, neuroleptic sensitivity (McKeith 1992). Conversely, L-DOPA treatment of parkinsonism can exacerbate the psychosis. Given that anticholinergic agents are effective in reducing symptoms of tremor in PD, there are theoretical reasons why 'pro-cholinergic' interventions such as cholinesterase inhibitors, which act to reduce breakdown of acetylcholine, might worsen the motor symptoms of PD (Thomas 2005).

\section{Drug licensing}

To date, rivastigmine is the only cholinesterase inhibitor that is licensed for the treatment of mild to moderate dementia in Alzheimer's disease and Parkinson's disease in the UK (Medicines and Healthcare products Regulatory Agency) and the USA (Federal Drug Authority). The use of donepezil and galantamine is only licensed in mild to moderate Alzkeimer's disease.

\section{O B J E C T I V E S}

To assess the efficacy, safety and tolerability of cholinesterase inhibitors in patients with dementia with Lewy bodies (LB), Parkinson's disease with dementia and cognitive impairment in Parkinson's disease (considered as a separate phenomena and also grouped together as LB disease).

\section{MET HO D S}

\section{Criteria for considering studies for this review}

\section{Types of studies}

Randomised, double-blind, placebo-controlled trials assessing the efficacy of treatment with cholinesterase inhibitors in DLB, PDD and cognitive impairment in Parkinson's disease (CIND-PD).

\section{Types of participants}

All patients with either DLB or PDD or cognitive impairment in Parkinson's disease. Coexisting Alzheimer's disease was not an exclusion.

\section{Types of interventions}

Any studies comparing any of the current cholinesterase inhibitors (donepezil, galantamine, rivastigmine, tacrine) at any dose, taken over any length of time, against placebo. 


\section{Types of outcome measures}

Outcome measures included the following.

1. Neuropsychiatric features (e.g. psychiatric symptoms, behavioural features); subgroup analysis of those with and without visual hallucinations.

2. Cognitive function; subgroup analysis of those with and without attentional deficits.

3. Activities of daily living.

4. Global assessments.

5. Quality of life, e.g. including maintenance of social functioning.

6. Effect on carers.

7. Institutionalization.

8. Effect on Parkinsonian features (e.g. tremor, rigidity).

9. Acceptability of treatment, as indicated by patient or carer assessment or by measurement of withdrawal from trials, or both.

10. Safety, as measured by severity and frequency of side effects and adverse events.

11. Deaths, including deaths during trials and time to death.

12. Heath economics.

\section{Search methods for identification of studies}

\section{Electronic searches}

We searched ALOIS (www.medicine.ox.ac.uk/alois), the Cochrane Dementia and Cognitive Improvement Group Specialised Register (on 30 August 2011). The search terms used were: PDD, parkinson, LBD, DLB, lewy.

ALOIS is maintained by the Trials Search Co-ordinator of the Cochrane Dementia and Cognitive Improvement Group and contains studies in the areas of dementia prevention, dementia treatment and cognitive enhancement in healthy people. The studies are identified from:

1. monthly searches of a number of major healthcare databases: MEDLINE, EMBASE, CINAHL, PsycINFO and LILACS;

2. monthly searches of a number of trial registers: ISRCTN; UMIN (Japan's Trial Register); the WHO portal (which covers ClinicalTrials.gov; ISRCTN; the Chinese Clinical Trials Register; the German Clinical Trials Register; the Iranian Registry of Clinical Trials and the Netherlands National Trials Register plus others);

3. a quarterly search of The Cochrane Library's Central Register of Controlled Trials (CENTRAL);

4. six-monthly searches of a number of grey literature sources: ISI Web of Knowledge Conference Proceedings; Index to Theses; Australasian Digital Theses.

To view a list of all sources searched for ALOIS see About ALOIS on the ALOIS website.

Details of the search strategies used for the retrieval of reports of trials from the healthcare databases, CENTRAL and conference proceedings can be viewed in the 'methods used in reviews' section within the editorial information about the Dementia and Cognitive Improvement Group.

Additional searches were performed in many of the sources listed above, to cover the timeframe from the last searches performed for ALOIS, to ensure that the search for the review was as up-to-date and as comprehensive as possible. The search strategies used can be seen in Appendix 1.

The latest search (August 2011) retrieved a total of 240 results. After a first assessment and de-duplication of these results the authors were left with 50 references to further assess.

\section{Searching other resources}

Reference lists of relevant studies were searched for additional trials.

\section{Data collection and analysis}

\section{Selection of studies}

Two review authors (MR, RMcS) independently selected trials for relevance using defined criteria in the current Cochrane Handbook for Systematic Reviews of Interventions.

\section{Asessment of methodological quality}

Review authors (MR, RMcS) independently assessed the quality of the trials according to the criteria given in the Cochrane Handbook. Where the review authors (MR, RMcS) identified bias and agreed that it was significant, trials were excluded from further analysis; reasons for such exclusion were given.

\section{Data extraction}

Data were extracted from the published reports (MR). Any uncertainty over inclusion or exclusion of a trial, methodological quality or data extraction were settled by discussion with a second review author (RMcS) who had previously extracted data in an earlier draft of this review.

The summary statistics required for each trial and each outcome for continuous data are the mean change from baseline, the standard error of the mean change, and the number of patients for each treatment group at each assessment. Where changes from baseline were not reported, the mean, standard deviation and the number of patients for each treatment group at the final time point were extracted, if available. Results from the donepezil groups in a study which compared two doses of donepezil were combined (Dubois 2007). For binary data the numbers in each treatment group and the numbers experiencing the outcome of interest were sought. The baseline assessment was defined as the latest available assessment prior to randomisation, but no longer than two months earlier. Data from titration phases prior to the randomised phase, or 
from open-label follow-up periods, were not used to assess safety or efficacy because patients were not randomised or treatments concealed.

\section{Analysis plan}

Data for trials in each 'condition' (that is PDD, DLB, CIND$\mathrm{PD})$ were considered separately on each outcome measure. Data for the conditions were also combined. It was intended that data for the three conditions would be considered both separately and combined together. Results were also analysed according to the cholinesterase used and the duration of the trial. Results were examined to establish whether any heterogeneity was explicable on the basis of the condition. Where there was no heterogeneity, then the focus in the text was determined by the number and quality of trials. Where the heterogeneity of results was high, as indicated by $\mathrm{I}^{2}>40 \%$, this was reported in the text.

\section{RE S U L T S}

\section{Description of studies}

See: Characteristics of included studies; Characteristics of excluded studies; Characteristics of ongoing studies.

Six trials met the inclusion criteria for this review and 1236 participants were randomised in total. Four of the trials were of a parallel group design and two were cross-over trials.

\section{Participants}

All participants were aged 18 years and over, with both males and females included in all of the trials. Four of the trials included participants with a diagnosis of Parkinson's disease with dementia (Aarsland 2002a; Dubois 2007; Emre 2004; Ravina 2005), of which Dubois 2007 remains unpublished. Leroi 2004 included patients with either Parkinson's disease with dementia or cognitive impairment in Parkinson's disease. Patients with dementia with Lewy Bodies were included in only one of the trials (McKeith 2000).

\section{Setting}

The trials were all conducted in the outpatient population. Three of the trials were multicenter studies (Dubois 2007; McKeith 2000; Emre 2004). Two of the trials took place in the United States of America (Leroi 2004; Ravina 2005), with the remaining trial taking place in Norway (Aarsland 2002a).

\section{Intervention}

Two of the trials compared the use of oral rivastigmine, up to 12 mg daily, with the use of placebo (Emre 2004; McKeith 2000). The remaining trials compared the use of oral donepezil to oral placebo. Three of the trials (Aarsland 2002a; Leroi 2004; Ravina 2005) studied donepezil at the highest tolerated dose (up to 10 mg daily). Dubois 2007 compared the use of donepezil at two different doses (either $5 \mathrm{mg}$ or $10 \mathrm{mg}$ ) to placebo.

\section{Duration}

Four of the trials were 18 weeks or more in duration (Dubois 2007; Emre 2004; Leroi 2004; McKeith 2000). The remaining two trials lasted 10 weeks (Aarsland 2002a; Ravina 2005).

\section{Outcome measures}

- Global assessment

1. The Alzheimer's Disease Cooperative Study Clinician's Global Impression of Change (ADCS-CGIC) scale (Schneider 1997 ) is a 7-point scale providing a global rating of patient function in four areas: general, cognitive, behaviour and activities of daily living. Assessments should be performed by the same clinician with input from the patient and the caregiver.

- Cognitive function

1. Mini-Mental State Examination (MMSE) (Folstein 1975) evaluates cognition in five areas: orientation, immediate recall, attention and calculation, delayed recall, and language. Test scores range from 0 (severe impairment) to 30 (normal).

2. The cognitive part of the Alzheimer's Disease Assessment Scale (ADAS-Cog) (Rosen 1984) comprises 11 individual sections testing spoken language, recall of test instructions, word finding difficulty, following commands, naming objects, construction drawing, ideational praxis, orientation, word recall and word recognition. The maximum score is 70 , with higher scores representing greater impairment.

3. The Mattis Dementia Rating Scale (MDRS) (Mattis 1988) assesses cognitive function on five subscales: attention, initiationperseveration, construction, conceptualisation and memory.

4. The Cognitive Drug Research (CDR) Computerized Assessment System (Simpson 1991) power of attention tests evaluate simple and complex reaction times and digit vigilance. Scores are measured in milliseconds with higher scores indicating a worse performance.

5. The Delis-Kaplan Executive Function System (D-KEFS) Verbal Fluency test (Delis 2001) requires patients to produce as many words starting with a particular letter as they can in one minute. Higher scores indicate better performance.

6. The Ten Point Clock-Drawing test (Manos 1994) is used as a measure of spatial dysfunction and neglect. Scores range from 0 to 10 with higher results indicating better performance. 
7. Brief test of attention (BTA) (Schretlen 1997) is an auditory perception task that measures divided attention in the verbal-linguistic system. Raw scores range from 0 (severe impairment) to 20 (normal).

8. The Trail Making Test (TMT) (Reitan 1958) tests visual attention and task switching. It is divided into two parts: part A, containing only numbers; and part $\mathrm{B}$, in which the participant must alternate between numbers and letters. The time to complete the test is used as the performance measure.

9. The Verbal Fluency test (Barr 1996) assesses the efficiency of verbal retrieval, short-term memory and cognitive flexibility by asking the participant to name as many animals as he or she can in 60 seconds.

10. Hopkins Verbal Learning Test (Brandt 2001) is a brief verbal learning and memory test.

11. Developmental Test of Visual-Motor Integration (VMI) (Beery 1989) consists of copying 24 geometric forms. A higher score indicates a better performance.

- Behavioural disturbance

1. The 10-item Neuropsychiatric Inventory (NPI) (Cummings 1994) is a relatively brief interview that assesses 10 types of behavioural disturbance: delusions, hallucinations, dysphoria, anxiety, agitation or aggression, euphoria, disinhibition, irritability or lability, apathy and aberrant motor behaviour. Scores range from 0 (normal) to 120 (severely disturbed).

2. The Brief Psychiatric Rating Scale (BPRS) (Overall 1962) is used to measure psychiatric symptoms such as depression, anxiety, hallucinations and unusual behaviour. Each symptom is rated 1 to 7 according to severity.

- Activities of daily living (ADL)

1. The Alzheimer's Disease Cooperative Study activities of daily living inventory (ADCS-ADL) (Galasko 1997) is a scale for basic and complex abilities that has been validated in patients with dementia. The highest score is 78 and implies no impairment.

2. Unfied Parkinson's Disease Rating Scale (UPDRS) Activities of Daily Living is a subscale of the UPDRS (see below).

- Safety and tolerability

1. The Unified Parkinson's Disease Rating Scale (UPDRS) (Fahn 1987) is used to follow the longitudinal course of Parkinson's disease. It is divided into five sections: evaluation of mentation, behaviour and mood; self evaluation of activities of daily living; clinician-scored motor evaluation, severity of Parkinson's disease (Hoehn and Yahr); and the Schwab and England ADL scale. Higher scores imply more severe disease.

\section{Risk of bias in included studies}

\begin{abstract}
Allocation
Aarsland 2002a and McKeith 2000 provided details of adequate sequence generation and concealment. Emre 2004 provided good details of sequence generation but did not specify methods used to maintain concealment of allocation, whilst Leroi 2004 did not discuss the randomisation procedures followed. Neither Dubois 2007 nor Ravina 2005 provided any details of the allocation procedure.
\end{abstract}

\section{Blinding}

All the trials described the use of 'double-blind' methods but none of them described how this was achieved.

\section{Reporting of withdrawals or dropouts}

Dubois 2007 did not disclose whether any of the participants withdrew or dropped out during the study. All other trials reported the numbers of withdrawals and dropouts but only McKeith 2000 included all of these in the final analysis. Aarsland 2002a, Emre 2004 and Leroi 2004 only included participants that received at least one dose of the study medication and had at least one measurement at baseline and at one other time point in the efficacy analysis, using the last observation carried forward. One study (Ravina 2005) specified that participants had to have at least one visit in the second period to be included in the efficacy analysis. Three participants were included in the safety but not the efficacy analysis as data from both periods were required for the cross-over analysis.

\section{Selective reporting}

Aarsland 2002a only published primary outcomes of the study and the publication of the secondary outcome measures is still pending. The results of one trial (Dubois 2007) are only available in poster format and, due to the very limited details provided, only one of the efficacy variables could be included in this metaanalysis. Despite numerous attempts to contact the authors, no further details of the trial have been made available.

\section{Other sources of bias}

Two trials (Aarsland 2002a; Ravina 2005) were cross-over in design and were considered in accordance with the guidance of the Cochrane Handbook for Systematic Reviews of Interventions (Higgins 2008). Although dementia is a neuro-degenerative condition, the duration of the trials was considered to be too short for any significant disease progression to have occurred in that period. Neither of the two studies demonstrated a significant carry-over effect between the two phases of the trial. 


\section{Effects of interventions}

Table 1

\section{Global assessment}

Three trials comparing cholinesterase inhibitor treatment to placebo in PDD (Aarsland 2002a; Emre 2004; Ravina 2005) reported a difference in the ADCS-CGIC score of -0.38 , favouring the cholinesterase inhibitors ( $95 \%$ CI -0.56 to $-0.24, \mathrm{P}<0.0001$ ) (Figure 1). A therapeutic benefit of cholinesterase inhibitors was observed irrespective of the agent used and the duration of the trial (weighted mean difference (WMD) -0.62, 95\% CI - 1.13 to $0.10, \mathrm{P}=0.02$ for donepezil used for 10 weeks or less; and WMD $-0.35,95 \% \mathrm{CI}-0.54$ to $-0.16, \mathrm{P}=0.0003$ for rivastigmine used for 18 weeks or more).

Figure I. Forest plot of comparison: I Global Assessment, outcome: I.I Alzheimer's Disease Cooperative Study - Clinician's Global Impression of Change (ADCS-CGIC).

\begin{tabular}{|c|c|c|c|c|c|c|c|c|c|}
\hline \multirow[b]{2}{*}{ Study or Subgroup } & \multicolumn{3}{|c|}{ Cholinesterase Inhibitor } & \multicolumn{3}{|c|}{ Placebo } & \multicolumn{2}{|r|}{ Std. Mean Difference } & \multirow{2}{*}{$\begin{array}{l}\text { Std. Mean Difference } \\
\text { IV, Fixed, } 95 \% \mathrm{Cl}\end{array}$} \\
\hline & Mean & SD & Total & Mean & SD & Total & Weight & IV, Fixed, $95 \%$ Cl & \\
\hline Aarsland 2002a & 3.3 & 0.9 & 12 & 4.1 & 0.8 & 12 & $4.3 \%$ & $-0.91[-1.76,-0.06]$ & \\
\hline Emre 2004 & 3.8 & 1.4 & 329 & 4.3 & 1.5 & 165 & $88.1 \%$ & $-0.35[-0.54,-0.16]$ & \\
\hline Ravina 2005 & 3.58 & 0.77 & 19 & 3.95 & 0.85 & 19 & $7.5 \%$ & $-0.45[-1.09,0.20]$ & \\
\hline Total $(95 \% \mathrm{Cl})$ & & & 360 & & & 196 & $100.0 \%$ & $-0.38[-0.56,-0.20]$ & $\boldsymbol{\nabla}$ \\
\hline \multicolumn{4}{|c|}{$\begin{array}{l}\text { Heterogeneity: } \mathrm{Chi}^{2}=1.64, \mathrm{df}=2(\mathrm{P}=0.44) ;\left.\right|^{2}=0 \% \\
\text { Test for overall effect: } Z=4.21(P<0.0001)\end{array}$} & & & & & & $\begin{array}{cccc} & 1 & 1 & 1 \\
-2 & -1 & 0 & 1 \\
\text { xperimental } & \text { Favours co }\end{array}$ \\
\hline
\end{tabular}

Three trials reported response rates (Aarsland 2002a; Dubois 2007; Emre 2004). These favoured the cholinesterase inhibitor (OR 2.26, 95\% CI 1.04 to $4.91, \mathrm{P}=0.04$ ) but with high heterogeneity $\left(I^{2}=78 \%\right)$.

\section{Cognitive function}

Although there was no statistically significant difference in the MMSE between the control and treatment group for patients with DLB (McKeith 2000) (WMD 1.24, 95\% CI 0.28 to 2.76, P $=0.11$ ), a beneficial treatment effect was seen in PDD patients (Aarsland 2002a; Emre 2004; Ravina 2005) (WMD 1.09, 95\% CI 0.45 to $1.73, \mathrm{P}=0.0008$ ) and in PDD and CIND-PD patients (Aarsland 2002a; Emre 2004; Leroi 2004; Ravina 2005) (WMD $1.05,95 \%$ CI 0.42 to $1.68, \mathrm{P}=0.001$ ). Pooling all available data showed an improvement in the MMSE favouring treatment with cholinesterase inhibitors (WMD 1.08, 95\% CI 0.50 to $1.66, \mathrm{P}$ $=0.0003)$. Furthermore, cholinesterase inhibitors lead to an improvement in cognitive function in patients with PDD, as measured by the ADAS-Cog (Dubois 2007; Emre 2004; Ravina 2005) (WMD -2.72, 95\% CI -3.61 to - $1.83, \mathrm{P}<0.00001$ ) and the Delis-
Kaplan Executive Function System (Emre 2004) (WMD 2.80, $95 \%$ CI 1.47 to $4.13, \mathrm{P}<0.0001$ ). There was also a statistically significant improvement in the Trail Making Test $\mathrm{A}$ in patients with PDD or CIND-PD (Leroi 2004) (WMD -71.68, 95\% CI -108.44 to $-34.92, \mathrm{P}=0.0001)$. Cholinesterase inhibitor use had no statistically significant impact on the Mattis Dementia Rating Scale (MDRS) when used in patients with PDD alone (Emre 2004; Ravina 2005) (WMD 3.39, CI 95\% -4.06 to $10.84, \mathrm{P}=0.37$ ) or in patients with PDD or CIND-PD (Emre 2004; Leroi 2004; Ravina 2005) (WMD 3.70, 95\% CI -1.13 to $8.54, \mathrm{P}=0.30$ ). No significant difference between the two groups was observed using the Cognitive Drug Research Computerized Assessment system power of attention scale (Emre 2004) (WMD -173.70, 95\% CI 471.23 to $123.83, \mathrm{P}=0.25)$, the Ten Point Clock Drawing Test (Emre 2004) (WMD 1.10, 95\% CI -0.01 to 2.21, P = 0.05), Brief Test of Attention (Leroi 2004) (WMD 1.65, 95\% CI -0.82 to 4.12, $\mathrm{P}=0.19$ ), Trail Making Test B (Leroi 2004) (WMD -87.24, 95\% CI -202.89 to $28.41, \mathrm{P}=0.14$ ), Verbal Fluency Test (Leroi 2004) (WMD 6.63, 95\% CI -2.33 to $15.59, \mathrm{P}=0.15$ ), Hopkins Verbal Learning Test (Leroi 2004) (WMD 1.72, 95\% CI -2.93 
to 6.37, $\mathrm{P}=0.47)$ and the Developmental Test of Visual-Motor Integration (Leroi 2004) (WMD 0.03, 95\% CI -3.28 to 3.34, P $=0.99$ ).

In an overall assessment of the cognitive function domain, combining MMSE scores where available, and ADASCog scores where not, the pooled estimate of the effect of cholinesterase inhibitors on cognitive function measures was consistent with the presence of a therapeutic benefit (standardised mean difference (SMD) $0.34,95 \% \mathrm{CI}-0.46$ to $-0.23, \mathrm{P}<0.00001$ ) (Figure 2). The beneficial effect of cholinesterase inhibitors on cognitive function was observed in both the donepezil and rivastigmine groups (SMD $0.42,95 \%$ CI -0.58 to $-0.25, \mathrm{P}<0.00001$; SMD $-0.27,95 \%$ CI -0.44 to $-0.11, \mathrm{P}<0.001$, respectively).

Figure 2. Forest plot of comparison: 2 Cognitive function, outcome: 2.3 Combined: MMSE or ADASCog.

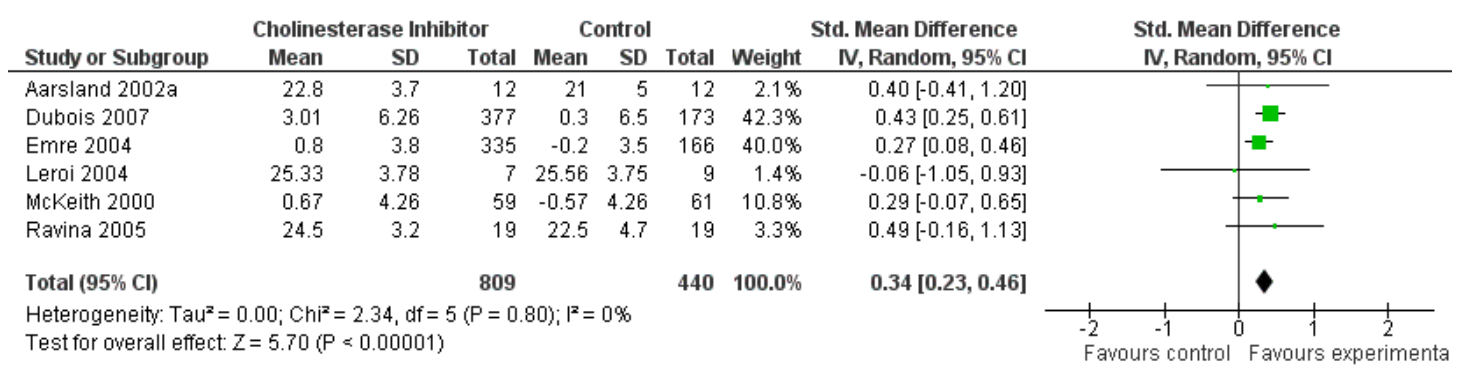

\section{Behavioural disturbance}

Analysis of the pooled continuous data relating to behavioural disturbance rating scales once again favoured treatment with cholinesterase inhibitors (SMD -0.20, 95\% CI -0.36 to -0.04, P = $0.01)$ (Figure 3). This effect was only seen in trials using rivastigmine (SMD $-0.21,95 \%$ CI -0.36 to $-0.06, \mathrm{P}=0.006$ ) and those lasting 18 weeks or longer (SMD $-0.21,95 \%$ CI -0.36 to $-0.06, \mathrm{P}$ $=0.005)$. Breakdown of the individual rating scales did not reveal any effect of the treatment on the Brief Psychiatric Rating Scale (Ravina 2005) (WMD -0.30, 95\% CI -5.89 to 5.25, P = 0.92) or the 12-item Neuropsychiatric Inventory (Leroi 2004) (WMD $3.30,95 \% \mathrm{CI}-13.75$ to $7.15, \mathrm{P}=0.54)$. Patients with DLB failed to improve their NPI-4 (McKeith 2000) (WMD -1.65, 95\% CI 4.33 to $1.03, \mathrm{P}=0.23$ ) or NPI-10 (McKeith 2000) (WMD -3.30, $95 \% \mathrm{CI}-8.14$ to $1.54, \mathrm{P}=0.18)$ scores on active treatment. Emre 2004 showed an improvement of -2.00 (95\% CI -3.91 to -0.09 , $\mathrm{P}=0.04)$ in NPI-10 in PDD patients treated with cholinesterase inhibitors. Hallucinations were less frequently reported in the active treatment group than the placebo group, however this was not statistically significant (Dubois 2007; Emre 2004) (46/739 versus 33/352; OR $0.64,95 \%$ CI 0.40 to $1.02, \mathrm{P}=0.06$ ). There was a risk of bias due to selective reporting of this outcome, which was not available from the large Dubois 2007 study and Aarsland 2002a. 
Figure 3. Forest plot of comparison: 3 Behavioural Disturbance, outcome: 3.5 Combined.

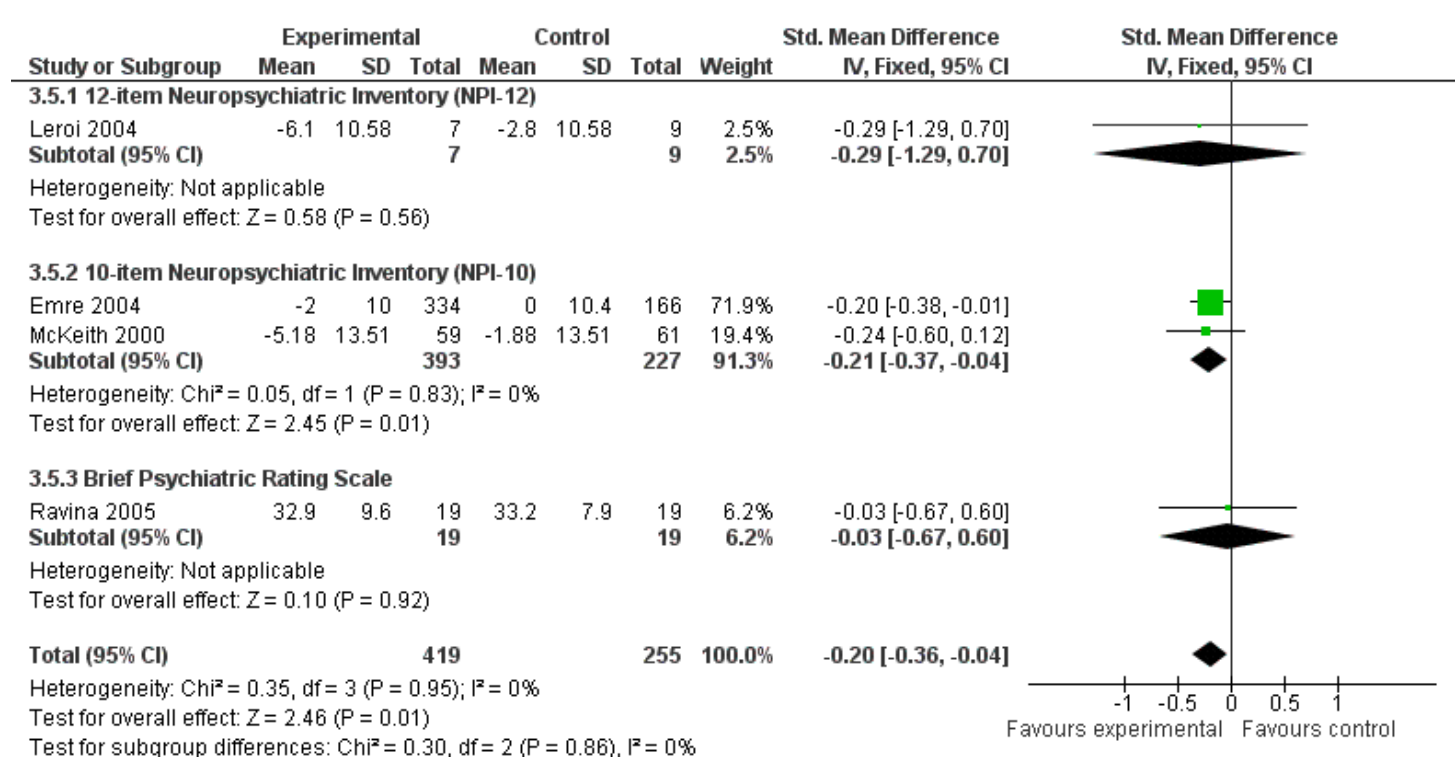

\section{Activities of daily living}

There was an improvement in the Alzheimer's Disease Cooperative Study activities of daily living rating scale (Emre 2004) (WMD $2.50,95 \% \mathrm{CI} 0.43$ to $4.57, \mathrm{P}=0.02$ ), with no difference observed using the UPDRS activities of daily living rating scale (Leroi 2004) (WMD 0.84, 95\% CI -6.24 to 7.92, P = 0.82). Combined data favoured treatment with cholinesterase inhibitors (SMD -0.20, $95 \%$ CI -0.38 to $-0.02, \mathrm{P}=0.03)$.

\section{Safety and tolerability}

Both the total number of dropouts and the number of dropouts due to adverse events were significantly higher in the treatment group as compared to the patients receiving placebo (128/465 versus $45 / 279$; OR $1.94,95 \%$ CI 1.33 to $2.84, \mathrm{P}=0.0006$ and $73 / 430$ versus $22 / 247$; OR $2.12,95 \%$ CI 1.27 to $3.55, \mathrm{P}=0.004$ ). The placebo group experienced significantly fewer adverse events (668/842 versus $318 / 452$; OR $1.64,95 \%$ CI 1.26 to $2.15, \mathrm{P}=$ $0.0003)$, although the number of adverse events that were judged to be severe was not significantly different between the two groups ( $21 / 73$ versus $15 / 73$; OR $1.60,95 \%$ CI 0.68 to $3.81, \mathrm{P}=0.28)$. Interestingly, the increase in the number of dropouts and adverse events in the treatment group were significant in studies using rivastigmine (117/421 versus 42/240; OR 1.82 , $95 \%$ CI 1.22 to $2.71, \mathrm{P}=0.003$ and $357 / 421$ versus $173 / 240$; OR $2.28,95 \%$ CI 1.53 to $3.38, \mathrm{P}<0.0001$, respectively) but not in the studies using donepezil (11/44 versus 3/39; OR 3.64, $95 \%$ CI 0.99 to $13.46, \mathrm{P}=0.05$ and $311 / 421$ versus $145 / 212$; OR $1.24,95 \% \mathrm{CI}$ 0.86 to $1.80, \mathrm{P}=0.25$, respectively). Parkinsonian symptoms were reported more commonly in the treatment group (139/739 versus 40/352; OR $1.88,95 \%$ CI 1.28 to $2.75, \mathrm{P}=0.001$ ), however this did not have a significant impact on the UPDRS (total and motor) scores (SMD -0.07, 95\% CI -0.42 to $0.29, \mathrm{P}=0.71$ ) (Figure 4). Although tremor was more commonly reported in the treatment groups (64/739 versus 12/352; OR 2.71, 95\% CI 1.44 to 5.09, $P=0.002)$, the same was not true of falls (43/739 versus $16 / 352$; OR $1.29,95 \%$ CI 0.72 to $2.33, \mathrm{P}=0.39$ ). Fewer deaths occurred in the treatment group when compared to the placebo group (4/ 465 versus 9/279; OR $0.28,95 \% \mathrm{CI} 0.09$ to $0.84, \mathrm{P}=0.03$ ). 
Figure 4. Forest plot of comparison: 5 Safety and Tolerability, outcome: 5.9 Unified Parkinson's Disease Rating Scale (UPDRS).

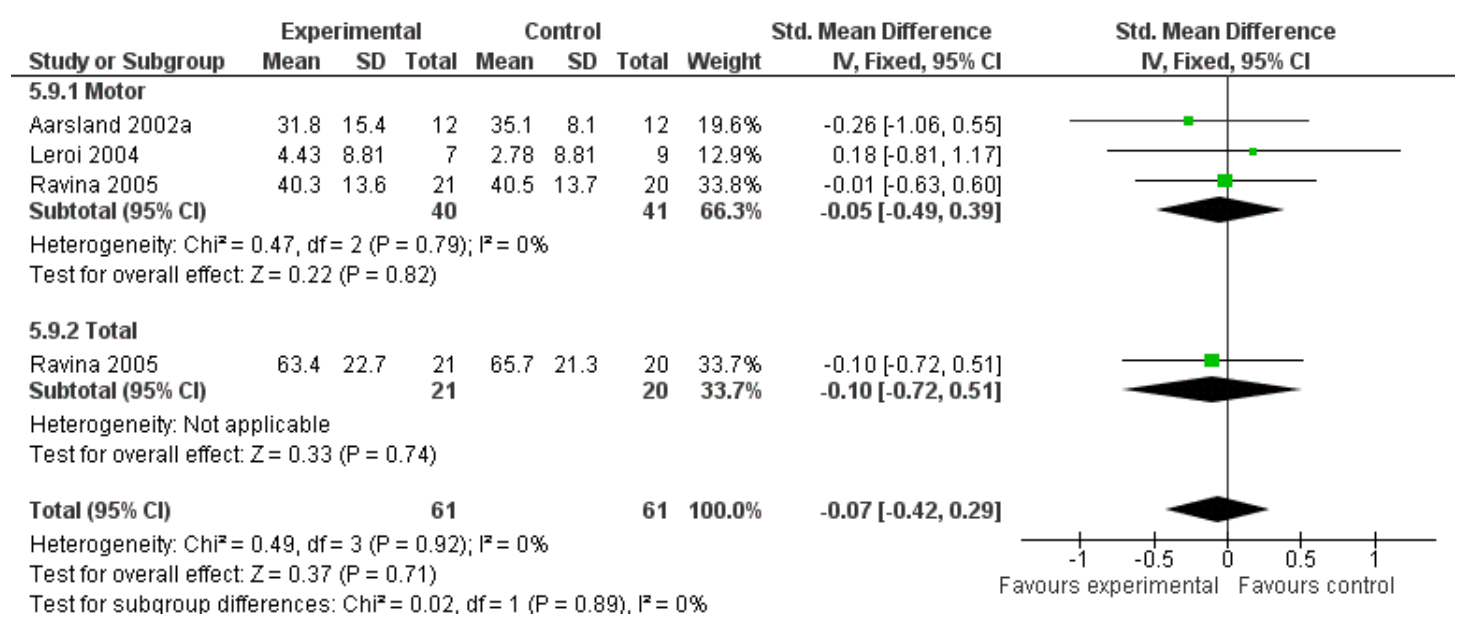

the same in both groups. Indeed, death rates were lower amongst those taking the active drug than placebo, though this is based on small numbers. Although parkinsonian symptoms, and tremor in particular, were reported more frequently as adverse effects in patients receiving cholinesterase inhibitors, this did not seem to have an impact on the Parkinson's disease severity rating scales.

We identified six trials to help us to assess the efficacy, safety and tolerability of cholinesterase inhibitors in dementia with Lewy bodies (DLB), Parkinson's disease with dementia (PDD) and cognitive impairment in Parkinson's disease (CIND-PD). Where possible, we considered outcome measures for the separate diseases as well as combining the data available to estimate the general effect of cholinesterase inhibitors on Lewy body disease.

Currently available evidence suggests that cholinesterase inhibitors improve global assessment measures in patients with PDD, with no data for DLB and CIND-PD being available. As there was no evidence of a positive impact of cholinesterase inhibitors on cognitive function and behavioural disturbance rating scales in patients with DLB, the overall response in favour of using cholinesterase inhibitors is likely to be due to the effect seen in patients with PDD. As only one of the six trials included in this meta-analysis randomised patients with DLB, the over-representation of patents with PDD could have a substantial effect on the overall effects. The effect of cholinesterase inhibitors on measures of activities of daily living was not assessed in the DLB population but was statistically significant in the very small trial which included both patients with PDD and CIND-PD.

The trials that were included provided evidence that cholinesterase inhibitors were not as well tolerated as placebo, with significantly more adverse effects and dropouts seen in the active treatment group. Reassuringly, the frequency of severe adverse effects was

An important limitation of the current study lies in the incomplete public presentation of data from the important Dubois 2007 study, which was sponsored by Pfizer. The study was completed prior to current US legislation on trial registration.

\section{A U THORS, CONCLUSIONS Implications for practice}

The currently available evidence supports the use of cholinesterase inhibitors in patient with PDD and CIND-PD, with a positive impact on global assessment, cognitive function, behavioural disturbance and activities of daily living rating scales. The effect of cholinesterase inhibitors on patients with DLB has only been investigated in one small study and, therefore, evidence for their use in this patient group is less clear.

\section{Implications for research}

Patients with DLB were under-represented in this meta-analysis and further randomised evidence is required to reduce the uncertainty of the effects that cholinesterase inhibitors have in this patient group. A large trial of donepezil in patients with CIND-PD is due to commence in 2012 (Burn 2009). 


\section{ACKNOWLEDGEMENTS}

The authors gratefully acknowledge the contributions of the consumer editor, Margaret Bullard. We are also grateful to David Beversdorf for sharing the data from his study with us.

\section{REFERENCES}

\section{References to studies included in this review}

Aarsland 2002a \{published data only\}

* Aarsland D, Laake K, Larsen JP, Janvin C. Donepezil for cognitive impairment in Parkinson's disease: a randomized control trial. Journal of Neurology, Neurosurgery, and Psychiatry 2002;72:708-12.

Dubois 2007 \{unpublished data only\} Dubois B, Tolosa E, Kulisevsky J, Reichman H, Jones $\mathrm{R}$, Burn D, et al.Efficacy and safety of donepezil in the treatment of Parkinson's disease patients with dementia. Alzheimer's and Parkinson's Disease Congress, Salzburg. 2007.

Emre 2004 \{published data only\}

Burn D, Emre M, McKeith I. Reponse to rivastigmine in patients with and without visual hallucinations in dementia associated with Parkinson's disease (EXPRESS study group). 57th Annual meeting American Academy of Neurology. April 2005. [: http:www.abstracts2view.com/aan/] Burn D, Emre M, McKeith I, De Deyn PP, Aarsland D, $\mathrm{Hsu} \mathrm{C}$, et al.Effects of rivastigmine in patients with and without visual hallucinations in dementia associated with Parkinson's disease. Movement Disorders 2006; Vol. 21, issue 11:1899-907.

Dujardin K, Devos D, Duhem S, Destee A, Marie R-M, Durif F, et al.Utility of the Mattis dementia rating scale to assess the efficacy of rivastigmine in dementia associated with Parkinson's disease. Journal of Neurology 2006; Vol. 253, issue 9:1154-9.

* Emre M, Aarsland D, Albanese A, Byrne EJ, Deuschl G, DeDeyn PP, et al.Rivastigmine for Dementia Associated with Parkinson's Disease. New England Journal of Medicine 2004;351:2509-18.

Emre M, Onofrj M, Tekin S, Quarg P, Lane R, Express Study Group. Benefits of rivastigmine in Parkinson's disease dementia: Results from the EXPRESS study. Neurobiology of Aging 2004;25 Suppl 2:19.

Lees AJ. An extension study to investigate the effect of Exelon (rivastigmine) on Parkinson's disease dementia. National Research Register 2003.

Olin JT, Aarsland D, Meng X. Rivastigmine in the treatment of dementia associated with Parkinson's disease: effects on activities of daily living. Dementia and Geriatric Cognitive Disorders 2010; Vol. 29, issue 6:510-5.

Olin JT, Aarsland D, Meng X. Rivastigmine in the treatment of dementia associated with Parkinson's disease (PDD): subscale analysis of activities of daily living (ADL). Annals of Neurology. Conference: 134th American Neurological
Association, ANA Meeting Baltimore, MD United States. October 2009. Conference Publication 2009; Vol. 66:S45. Poewe W, EXPRESS Study Group. Long-term benefits of rivastigmine in dementia associated with Parkinson's disease: An open-label extension study. 57th Annual Meeting of the American Academy of Neurology, Miami Beach. April 2005.

Schmitt F, A, Aarsland D, Bronnick K, S, Xiangyi Meng Tekin $S$, et al.Evaluating rivastigmine in mild-tomoderate Parkinsons disease dementia using ADAS-cog items. American Journal of Alzheimer's Disease and other Dementias 2010; Vol. 25, issue 5:407-13.

Schmitt F, Farlow M, Olin J. Effects of rivastigmine on executive function in parkinson's disease dementia: Results from a 24-week placebo-controlled clinical trial. Annals of Neurology. Conference: 134th American Neurological Association, ANA Meeting Baltimore, MD United States. October 2009. Conference Publication 2009; Vol. 66 Suppl:48.

Schmitt FA, Aarsland D, Bronnick KS, Olin JT, Meng $\mathrm{X}$. Evaluating cognitive effects of oral rivastigmine using subscales and items of the ADAS-cog in patients with mild to moderate Parkinson's disease dementia. American Journal of Geriatric Psychiatry. Conference: 2010 AAGP Annual Meeting Savannah, GA United States. March 2010. Conference Publication 2010; Vol. 18 Suppl 1, issue 3:79. Schmitt FA, Aarsland DAG, Bronnick KS, Olin JT, Meng $\mathrm{X}$. Evaluating cognitive effects of oral rivastigmine using subscales and items of the Adas-Cog in patients with mild to moderate Parkinson's disease dementia. Neurology 2010; Vol. 74, issue 9:A270.

Schmitt FA, Farlow MR, Meng X, Tekin S, Olin JT. Efficacy of rivastigmine on executive function in patients with Parkinson's disease dementia. CNS Neuroscience \& Therapeutics 2010; Vol. 16, issue 6:330-6.

Wesnes KA, McKeith I, Edgar C, Emre M, Lane R. Benefits of rivastigmine on attention in dementia associated with Parkinson disease. Neurology 2005;65:1654-6.

Leroi 2004 \{published data only\}

Leroi I, Brandt J, Reich SG, Lyketsos CG, Grill S, Thompson R, Marsh L. Randomized placebo-controlled trial of donepezil in cognitive impairment in Parkinson's disease.. International Journal of Geriatric Psychiatry 2004; 19(1): $1-8$.

McKeith 2000 \{published data only\} Byrne J. Treatment of Lewy body dementia with Exelon. National Research Register 2000. [MEDLINE: http:// 
www.update-software.com/NRR]

Del Ser T. Efficacy of cholinesterase inhibitors in lewy body dementia. Sixth International Stockholm/Springfield Symposium on Advances in Alzheimer Therapy; 5-8 April 2000, Stockholm, Sweden 2000:51.

Del Ser T, McKeith I, Anand R, Cicin-Sain A, Ferrara R, Spiegel R. Dementia with Lewy bodies: findings from an international multicentre study. International Journal of Geriatric Psychiatry 2000;15(11):1034-45.

McKeith I, Del Ser T, Anand R, et al.Rivastigmine provides symptomatic benefit in dementia with Lewy bodies: findings from a placebo-controlled international multicenter study. Neurology 2000e; Vol. 54 Suppl 3:A450.

McKeith I, Del Ser T, Spano P, Emre M, Wesnes K, Anand $\mathrm{R}$, et al.Efficacy of rivastigmine in dementia with Lewy bodies: a randomised, double-blind, placebo-controlled international study. Lancet 2000f; Vol. 356, issue 9247 : 2031-6.

Rossor MN. A prospective, multicentre, randomised double blind placebo controlled exploratory study to evaluate the safety, tolerability and efficacy of a new drug in patients suffering from probable dementia with Lewy bodies. National Research Register http://www.updatesoftware.com/NRR 1999.

Wesnes KA, McKeith IG, Ferrara R, Emre M, Del Ser T, Spano PF, et al.Effects of rivastigmine on cognitive function in dementia with Lewy bodies: a randomised placebocontrolled international study using the Cognitive Drug Research computerized assessment system. Dementia and Geriatric Cognitive Disorders 2002;13:183-92.

Ravina 2005 \{published data only\}

Ravina B, Putt M, Siderow A, Farrar JT, Gillespie M, Crawley A, et al.Donepezil for dementia in Parkinson's disease: a randomised, double-blind, placebo controlled, crossover study. Journal of Neurology, Neurosurgery, and Psychiatry 2005;76(7):934-9.

\section{References to studies excluded from this review}

\section{Aarsland 2002 \{published data only\}}

* Aarsland D. Galantamine for Parkinson's disease with dementia. European Neuropsychopharmacology 2002;12 Suppl:378-9.

Aarsland D, Hutchinson M, Larsen JP. Cognitive, psychiatric and motor response to galantamine in Parkinson's disease with dementia. International Journal of Geriatric Psychiatry 2003;18(10):937-41.

Adler 2011 \{published data only\} Adler G, Christenn M, Bektas M, Ko-Inoshishi Y, Kupsch A, Scholz E, et al.Rivastigmine treatment in Parkinson's disease dementia: short-term cholinergic effects are correlated with six-month treatment response. Alzheimer's and Dementia. Conference: Alzheimer's Association International Conference, AAIC 11 Paris France. 16-21 July 2011. Conference Publication 2011; Vol. 7 Suppl 1, issue 4:776.

\section{Anand 2000 \{published data only\}}

Anand R, Enz A, Novartis Pharmaceuticals Corporation. Effects of rivastigmine extend beyond symptomatic treatment in patients with Alzheimer's disease(AD): new clinical studies. Sixth International Stockholm/Springfield Symposium on Advances in Alzheimer Therapy; April 5-8, 2000; Stockholm, Sweden 2000:29.

Barone 2008 \{published data only\} Barone P, Burn DJ, van Laar T, Hsu C, Poewe W, Lane RM. Rivastigmine versus placebo in hyperhomocysteinemic Parkinson's disease dementia patients. Movement Disorders 2008; Vol. 23, issue 11:1532-40.

Barone 2010 \{published data only\}

Barone P, De Deyn P, Emre M, Kulisevsky J, Poewe W, Pourcher E, et al.Baseline data from a long-term safety study of rivastigmine capsules and patch in mild to moderate Parkinson's disease dementia. Movement Disorders. Conference: 14th International Congress of Parkinson's Disease and Movement Disorders Buenos Aires Argentina. 13-17 June 2010. Conference Publication 2010; Vol. 25 Suppl:486-7.

Bergman 2002 \{published data only\}

Bergman J, Lerner V. Successful use of donepezil for the treatment of psychotic symptoms in patients with Parkinson's disease.. Clinical Neuropharmacology 2002;25 (2):107-10.

Bergman 2003 \{published data only\} Bergman J, Brettholz I, Shneidman M, Lerner V. Donepezil as add-on treatment of psychotic symptoms in patients with dementia of the Alzheimer's type.. Clinical neuropharmacology 2003;26(2):88-92.

Beversdorf 2004 \{published data only\}

Beversdorf DQ, Warner JL, Davis RA, Sharma UK, Nagaraja HN, Scharre DW. Donepezil in the treatment of dementia with Lewy bodies. American Journal of Geriatric Psychiatry 2004;12(5):542-4.

Brashear 2004 \{published data only\} Brashear A, Kuhn ER, Lane KA, Farlow MR, Unverzagt FW. A double-blind placebo-controlled trial of donepezil in patients with Parkinson's disease and related dementia. Neurology 2004;62 Suppl(7):5.

Chung 2010 \{published data only\} Chung KA, Lobb BM, Nutt JG, Horak FB. Effects of a central cholinesterase inhibitor on reducing falls in Parkinson disease. Neurology 2010; Vol. 75, issue 14: 1263-9.

Cummings 2010 \{published data only\} Cummings J, Emre M, Aarsland D, Tekin S, Dronamraju N, Lane R. Effects of rivastigmine in Alzheimer's disease patients with and without hallucinations. Journal of Alzheimer's Disease 2010; Vol. 20, issue 1:301-11.

De Deyn 2011 \{published data only\} De Deyn P, Poewe W, Barone P, Emre M, Kulisevsky J, Pourcher E, et al.Results of a long-term safety study of rivastigmine capsules and patch in patients with 
mild to moderate dementia associated with Parkinson's disease. Neurodegenerative Diseases. Conference: 10th International Conference AD/PD - Alzheimer's and Parkinson's Diseases: Advances, Concepts and New Challenges Barcelona Spain. 9-13 March 2011. Conference Publication 2011; Vol. 8.

\section{Fabbrini 2002 \{published data only\}}

Fabbrini G, Barbanti P, Aurilia C, Pauletti C, Lenzi GL, Meco G. Donepezil in the treatment of hallucinations and delusions in Parkinson's disease. Neurological Sciences 2002; 23:41-3.

\section{Fogelson 2003 \{published data only\}}

Fogelson N, Kogan E, Korczyn AD, Giladi N, Shabtai H, Neufeld MY. Effects of rivastigmine on the quantitative EEG in demented parkinsonian patients. Acta Neurologica Scandinavica 2003;107(4):252-5.

Foy 2000 \{published data only\}

Foy C. The non-dopaminergic neuropharmacology of idiopathic Parkinson's Disease. Thesis submitted in fulfilment for a Doctor of Philosophy, Section of Clinical Neurology, University of Sheffield (accessed from the British Library) 2000.

Grunewald RA. Investigation of the effects of rivastigmine on cognition in Parkinson's disease. National Research Register 1999.

\section{Fujita 2010 \{published data only\}}

Fujita Y, Takebayash M. Efficacy of low-dose donepezil for visual hallucinations in a patient with dementia with Lewy bodies. Psychiatry and Clinical Neurosciences 2010; Vol. 64, issue 3:336.

\section{Giladi 2003 \{published data only\}}

Giladi N, Shabtai H, Gurevich T, Benbunan B, Anca M, Korczyn AD. Rivastigmine for dementia in patients with Parkinson's disease. Acta Neurologica Scandinavica 2003; 108:368-73.

\section{Gustavsson 2009 \{published data only\}}

Gustavsson A, Van Der Putt R, Jonsson L, McShane R. Economic evaluation of cholinesterase inhibitor therapy for dementia: comparison of Alzheimer's disease and Dementia with Lewy bodies. International Journal of Geriatric Psychiatry 2009; Vol. 24, issue 10:1072-8.

\section{Hutchinson 1996 \{published data only\}}

Hutchinson M, Fazzini E. Cholinesterase inhibition in Parkinson's disease. Journal of Neurology, Neurosurgery, and Psychiatry 1996;61:324-5.

Korczyn 2001 \{published data only\}

Korczyn AD, Shabati H, Benbunan B, Gurevich T, Anca M, Sidis S, Giladi N. The effect of treatment with rivastigmine (Exelon) on cognitive functions of patients with dementia and Parkinson's disease. Parkinsonism \& Related Disorders 2001;7 Suppl:61.

\section{Lanctot 2000 \{published data only\}}

Lanctot KL, Hermann N. Donepezil for behavioural disorders associated with Lewy bodies: a case series. International Journal of Geriatric Psychiatry 2000;15:183-8.

\section{Linsarazo 2005 \{published data only\}}

Linsarozo G, Lasa A, van Blercom N. Efficacy and safety of donepezil in cognitive impairment in Parkinson's disease: a pilot study. Clinical Neuropharmacology 2005;28(4):176-8.

Litvinenko 2008 \{published data only\}

Litvinenko IV, Odinak MM, Mogil'naya VI, Emelin AYU. Efficacy and safety of galantamine (Reminyl) for dementia in patients with Parkinson's disease (an open controlled trial). Neuroscience and Behavioral Physiology 2008; Vol. 38, issue 9:937-45.

\section{McKeith 2000a \{published data only\}}

McKeith IG. A pilot study into the effects of donepezil on cognitive impairment and neuropsychiatric features in patients with dementia with Lewy bodies and Parkinson's disease. National Research Register 2000a.

\section{McLaren 2003 \{published data only\}} McLaren AT, Allen J, Murray A, Ballard CG, Kenny RA. Cardiovascular effects of donepezil in patients with dementia. Dementia and Geriatric Cognitive Disorders 2003; 15:183-8.

Minett 2003 \{published data only\}

Minett TS, Thomas A, Wilkinson LM, Daniel SL, Sanders J, Richardson J, et al. What happens when donepezil is suddenly withdrawn? An open label trial in dementia with Lewy bodies and Parkinson's disease with dementia. International Journal of Geriatric Psychiatry 2003;18(11): 988-93.

Mori 2006 \{published data only\}

Mori S, Mori E, Iseki E, Kosaka K. Efficacy and safety of donepezil in patients with dementia with Lewy bodies: preliminary findings from an open-label study. Psychiatry and Clinical Neurosciences 2006;60(2):190-5.

\section{Olin 2010a \{published data only\}}

Olin JT, Bhatnagar V, Reyes P, Koumaras B, Meng X, et al.Safety and tolerability of rivastigmine capsule with memantine in patients with probable Alzheimer's disease: A 26-week, open-label, prospective trial (Study ENA713B US32). International Journal of Geriatric Psychiatry 2010; Vol. 25, issue 4:419-26.

Pakrasi 2006 \{published data only\}

Pakrasi S, Thomas A, Mosimann UP, Cousins DA, Burn DJ, O'Brien JT, McKeith IG. Cholinesterase inhibitors in advanced dementia with Lewy bodies: increase or stop? . International Journal of Geriatric Psychiatry 2006;21(8): 719-21.

Reading 2001 \{published data only\} Reading PJ, Luce AK, McKeith IG. Rivastigmine in the treatment of Parkinson's psychosis and cognitive impairment: preliminary findings from an open trial. Movment Disorders 2001;16:1171-95.

\section{Rektorova 2004 \{published data only\}}

Rektorova I. Effect of donepezil on dementia in Parkinson's disease and Alzheimer's disease: a pilot study [Ucinek donepezilu na demenci u parkinonovy nemoci a alzheimerovy nemoci. pilotni studie]. Ceska a Slovenska Neurologie a Neurchirurgie 2004;67(5):359-63. 
Rosengarten 2010 \{published data only\}

Rosengarten B, Dannhardt V, Burr O, Pohler M, Rosengarten S, Oechsner M, et al.Neurovascular coupling in Parkinson's disease patients: effects of dementia and acetylcholinesterase inhibitor treatment. Journal of Alzheimer's Disease 2010; Vol. 22, issue 2:415-21.

Samuel 2000 \{published data only\}

Samuel W, Caligiuri M, Galasko D, Lacro J, Marini M, McClure FS, et al.Better cognitive and psychopathologic response to donepezil in patients prospectively diagnosed as dementia with Lewy bodies: A preliminary study. International Journal of Geriatric Psychiatry 2000; Vol. 15, issue 9:794-802.

Satoh 2010 \{published data only\}

Satoh M, Ishikawa H, Meguro K, Kasuya M, Ishii H, Yamauchi S. Improved visual hallucination by donepezil and occipital glucose metabolism in dementia with Lewy bodies: the Osaki-Tajiri project. European Neurology 2010; Vol. 64, issue 6:337-44.

\section{Thomas 2005 \{published data only\}}

Thomas AJ, Burns A, Rowan EN, Littlewood E, Newby J, Cousins D, et al.A comparison of the efficacy of donepezil in Parkinson's disease with dementia and dementia with Lewy bodies. International Journal of Geriatric Psychiatry 2005;20(10):938-44.

Touchon 2006a \{published data only\} * Touchon J, Bergman H, Bullock R, Rapatz G, Nagel J, Lane R. Response to rivastigmine or donepezil in Alzheimer's patients with symptoms suggestive of concomitant Lewy body pathology. Current Medical Research and Opinion 2006;22(1):49.

Touchon 2006b \{published data only\} Touchon J, Bergman H, Bullock R. Erratum: Response to rivastigmine or donepezil in Alheimer's patients with symptoms suggestive of concomitant Lewy body pathology. Current Medical Research and Opinion 2006;22(1):45.

Van Laar 2001 \{published data only\}

Van Laar T, de Vries JJ, Nakhosteen A, Leenders KL. Rivastigmine as anti-psychotic treatment in patients with Parkinson's disease. Parkinsonism \& Related Disorders 2001; 7 Suppl:73.

Vasile 2010a \{published data only\}

Vasile D, Vasiliu O, Vasile ML, Terpan M, Grigorescu G, Bogdan V, et al.Comparative efficacy of cholinesterase inhibitors in dementia associated with Parkinson's disease. European Neuropsychopharmacology. Conference: 23rd European College of Neuropsychopharmacology, ECNP Congress Amsterdam, Netherlands. 28 August to 1 September 2010. Conference Publication 2010; Vol. 20 Suppl:553-4.

Vasile 2010b \{published data only\}

Vasile D, Vasiliu O. Management of cognitive symptoms in dementia associated with Parkinson's disease. Proceedings of the World Medical Conference 2010:284-6.

\section{Walker 2000b \{published data only\}}

Walker Z. Lewy body dementia: The investigation of pre and post synaptic dopaminergic receptors with SPET. NRR 2000. [MEDLINE: http://www.doh.gov.uk/nrr.htm]

Werber 2001 \{published data only\}

Werber EA, Rabey JM. The beneficial effect of cholinesterase inhibitors on patients suffering from Parkinson's disease and dementia. Journal of Neural Transmission 2001;108(11): 1319-25.

Wilcock 2000 \{published data only\} Wilcock GK. A double-blind, placebo-controlled, randomised, parallel group phase IIa study of the efficacy and safety of a novel therapy in the treatment of behavioural and psychological symptoms in subjects with dementia with Lewy bodies. National Research Register 2000e.

\section{References to ongoing studies}

\section{Anon 2004a \{published data only\}}

Anon. Donepezil to treat dementia in Parkinson's disease. ClinicalTrials.gov 2004

\section{Anon 2007a \{published data only\}}

Anon. Double-blind study of E2020 in patients with dementia with Lewy bodies - Phase II. ClinicalTrials.gov 2007.

Anon 2011 \{published data only\}

Anon. A study of E2020 in patients with dementia with Lewy bodies (DLB), followed by a long-term extension phase - Phase III. ClinicalTrials.gov 2011.

Burn 2009 \{published data only\}

Burn DJ. Multi-centre UK study of the acetylcholinesterase inhibitor donepezil in early dementia associated with Parkinson's disease (MUSTARDD-PD). ClinicalTrials.gov: http://clinicaltrials.gov/ct2/show/NCT01014858 2009.

Kurlan 2003 \{published data only\}

Kuran R. Treatment of agitation/psychosis in dementia/ parkinsonism. Alzheimer's Disease Education and Referral Centre (ADEAR) 2003.

\section{Marion 2003 \{published data only\}}

Marion MH. An open 24 week prospective, randomised, double-blind placebo controlled parallel group study of efficacy, tolerability and safety of 3-12 mg/day of Exelon and Exelon (rivastigmine) capsules in patients with Parkinson's disease dementia. National Research Register 2003.

\section{Additional references}

\section{Aarsland 2003}

Aarsland D, Andersen K, Larsen JP, Lolk A, Kragh-Sorensen P. Prevalence and characteristics of dementia in Parkinson disease: an 8-year prospective study. Archives of Neurology 2003;60:387-92.

\section{Aarsland 2005}

Aarsland D, Zaccai J, Brayne C. A systematic review of prevalence studies of dementia in Parkinson's disease. Movement Disorders 2005;20:1255-63. 


\section{Ballard 2006}

Ballard C, Ziabreva I, Perry R, Larsen JP, O'Brien J, McKeith $\mathrm{I}$, et al.Differences in neuropathologic characteristics across the Lewy body dementia spectrum. Neurology 2006;67(11): $1931-4$.

\section{Barr 1996}

Barr A, Brandt J. Word-list generation deficits in dementia. Journal of Clinical and Experimental Neuropsychology 1996; 18:810-22.

\section{Bedard 2003}

Bedard MA, Agid Y, Chouinard S, et al.Mental and Behavioural dysfunction in movement disorders. Totowa, NJ: Humana Press, 2003.

Beery 1989

Beery KE. Revised Administration, Scoring ad Teaching Manual for the Developmental Test of Visual-Motor Integration. Cleveland: Modern Curriculum Press, 1989.

\section{Bostrom 2006}

Bostrom F, Jonsson L, Minthon L, Londos E. Patients with Lewy body dementia use more resources than those with Alzheimer's disease. International Journal of Geriatric Psychiatry 2006; Vol. 22, issue 8:713-9.

\section{Braak 2006}

Braak H, Rub U, Del Tredici K. Cognitive decline correlates with neuropathological stage in Parkinson's disease. Journal of the Neurological Sciences 2006;248(1-2):255-8.

\section{Brandt 2001}

Brandt J, Benedict RHB. Hopkins Verbal Learning TestRevised, Professional Manual. Odessa, FL: Psychological Assessment Resources, Inc., 2001.

\section{Burn 2003}

Burn DJ, McKeith IG. Current treatment of dementia with Lewy bodies and dementia associated with Parkinson's disease. Movement Disorders 2003;18 Suppl 6:72-9.

\section{Burn 2006}

Burn DJ. Cortical Lewy body disease and Parkinson's disease dementia. Current opinions in neurology 2006;19(6):572-9.

\section{Cummings 1994}

Cummings JL, Mega M, Gray K, Rosenburg-Thompson S, Carusi DA, Gornbein J. The Neuropsychiatric Inventory: Comprehensive assessment of psychopathology in dementia. Neurology 1994;44:2308-13.

\section{Delis 2001}

Delis DC, Kaplan E, Kramer JH. Delis-Kaplan executive function system. San Antonio, Tex.: Psychological Corporation, 2001

Dubois 1997

Dubois B, Pillon B. Cognitive deficits in Parkinson's disease. Journal of Neurology 1997;244:2-8.

\section{Fahn 1987}

Fahn S, Elton RS, Members of the UPDRS Develpment Committee. Unified Parkinson's disease rating scale. In: Fahn S, Marsden CD, Goldstein M editor(s).
Recent Developments in Parkinson's Disease II. New York: Macmillan, 1987:153-63.

\section{Folstein 1975}

Folstein NF, Folstein SE, McHugh PR. Mini-Mental State: a practical method for grading the cognitive state of patients for the clinician. Journal of Psychiatric Research 1975;12: 189-98.

\section{Galasko 1997}

Galasko D, Bennett D, Sano M, et al.An inventory to assess activities of daily living for clinical trials in Alzheimer's disease. The Alzheimer's Disease Cooperative Study. Alzheimer Disease and Associated Disorders 1997;11 Suppl 2: 533-9.

\section{Higgins 2008}

Higgins JPT, Deeks JJ, Altman DG (editors). Chapter 16: Special topics in statistics. In: Higgins JPT, Green S editor(s). Cochrane Handbook for Systematic Reviews of Interventions. Chichester (UK): John Wiley \& Sons, 2008.

\section{Jellinger 1994}

Jellinger KA, Bancher CH, Fischer P. Neuropathological correlates of mental dysfunction in Parkinson's disease. In: Wolters EC, Scheltens PH editor(s). Mental Dysfunction in Parkinson's Disease. Dordrecht: ICG Printing, 1994: 141-61.

Lee 2006

Lee VM, Trojanowski JQ. Mechanisms of Parkinson's disease linked to pathological alpha-synuclein: new targets for drug discovery. Neuron 2006;52(1):33-8.

\section{Lippa 1998}

Lippa CF, Johnson R, Smith TW. The medial temporal lobe in dementia with Lewy bodies: a comparative study with Alzheimer's disease. Annals of Neurology 1998;43(1):102-6.

\section{Maidment 2006}

Maidment I, Fox C, Boustani M. Cholinesterase inhibitors for Parkinson's disease dementia. Cochrane Database of Systematic Reviews 2006, Issue 1. [DOI: 10.1002/ 14651858.CD004747.pub2]

\section{Manos 1994}

Manos PJ, Wu R. The ten point clock drawing test: a quick screen and grading method for cognitive impairment in medical and surgical patients. International Journal of Psychiatry in Medicine 1994;24:229-44.

\section{Mattis 1988}

Mattis S. Dementia Rating Scale (DRS) Professional Manual. Odessa, FL: Psychological Assessment Resources, Inc., 1988.

\section{McKeith 1992}

McKeith I, Fairbairn A, Perry R, Thompson P, Perry E. Neuroleptic sensitivity in patients with senile dementia of Lewy body type. BMJ 1992;305:673-8.

\section{McKeith 1996}

McKeith IG, Galasko D, Kosaka K, Perry EK, Dickson DW, Hansen LA, et al.Consensus guidelines for the clinical and pathologic diagnosis of dementia with Lewy bodies 
(DLB): report of the consortium on DLB international workshop. Neurology 1996;47:1113-24.

\section{McKeith 2005}

McKeith IG, Dickson DW, Lowe J, Emre M, O’Brien JT, Feldman H, et al.Diagnosis and management of dementia with Lewy bodies. Third report of the DLB consortium.. Neurology 2005;65:1863-72.

\section{Nakano 1984}

Nakano I, Hirano A. Parkinson's disease: neuron loss in the nucleus basalis without concomitant Alzheimer's disease. Annals of Neurology 1984;15:415-8.

\section{Olanow 2006}

Olanow CW, McNaught KS. Ubiquitin-proteasome system and Parkinson's disease. Movement Disorders 2006;21(11): 1806-23.

\section{Overall 1962}

Overall JE, Gorham DR. The Brief Psychiatric Rating Scale. Psychological Reports 1962;10:790-812.

\section{Perry 1994}

Perry EK, Haroutunian V, Davis KL, et al.Neocortical cholinergic activities differentiate Lewy body dementia from classical Alzheimer's disease. Neuroreport 1994;5(7):747-9.

\section{Reitan 1958}

Reitan RM. Validity of the Trail Making Test as an indicator of organic brain damage. Perceptual and Motor Skills 1958; 8:271-6.

\section{Rosen 1984}

Rosen WG, Mohs RC, Davis K. A new rating scale for Alzheimer's disease. American Journal of Psychiatry 1984; 141:1356-64.

\section{Schneider 1997}

Schneider LS, Olin JT, Doody RS, et al.Validity and reliability of the Alzheimer's Disease Cooperative Study Clinical Global Impression of Change. Alzheimer Disease and Associated Disorders 1997;11 Suppl 2:22-32.

\section{Schretlen 1997}

Schretlen D. Brief Test of Attention Professional Manual. Odessa, FL: Psychological Assessment Resources, Inc., 1997.

\section{Simpson 1991}

Simpson PM, Surmon DJ, Wesnes KA, Wilcock GK. The cognitive assessment system for the demented patients: a validation study. International Journal of Geriatric Psychiatry 1991;6:95-102.

\section{Wild 2003}

Wild R, Pettit T, Burns A. Cholinesterase inhibitors for dementia with Lewy bodies. Cochrane Database of Systematic Reviews 2003, Issue 3. [DOI: 10.1002/ 14651858.CD003672]

\section{Williams 2009}

Williams SS, Williams J, Combrinck M, Christie S, Smith $\mathrm{AD}, \mathrm{McShane}$ R. Olfactory impairment is more marked in patients with mild dementia with Lewy bodies than those with mild Alzheimer disease. Journal of Neurology, Neurosurgery, and Psychiatry 2009;80(6):667-70.

\section{Zaccai 2005}

Zaccai J, McCracken C, Brayne C. A systematic review of prevalence and incidence studies of dementia with Lewy bodies. Age and Ageing 2005;34:561-6.

* Indicates the major publication for the study 


\section{CHARACTERISTICS OF STUDIES}

\section{Characteristics of included studies [ordered by study ID]}

\section{Aarsland 2002a}

\begin{tabular}{|c|c|}
\hline Methods & $\begin{array}{l}\text { Randomised, single centre, double-blind, cross-over, placebo-controlled. } \\
\text { Duration: } 10 \text { weeks. }\end{array}$ \\
\hline Participants & $\begin{array}{l}\text { Country: Norway } \\
\text { No. of centres: } 1 \\
\text { Diagnosis: definite or probable PD as per Larsen (Clinical diagnosis of Parkinson's dis- } \\
\text { ease. Proposal of diagnostic subgroups classified at different levels of confidence) AND } \\
\text { dementia due to PD by DSM-IV criteria. } \\
\text { Inclusions: age } 41-95 \text { years, mild-severe Parkinsonism (Hoehn and Yahr stage <5), clinical } \\
\text { evidence of decline in memory AND at least one other category of cognitive function } \\
\text { (starting at least } 1 \text { year after onset of parkinsonism), MMSE 16-26, on stable regimen } \\
\text { anti-Parkinsonian mediation for at least } 1 \text { month immediately preceding study and } \\
\text { throughout its duration, patient accompanied by care-giver (= informant). } \\
\text { Exclusions: brain disease except PD, other severe medical disorders, use of anticholinergic } \\
\text { drugs or psychtropic drugs with anticholinergic effects, use benzodiazepine medication } \\
\text { (except short-acting) in } 24 \text { hours before testing } \\
\text { Number of patients: } 14\end{array}$ \\
\hline Interventions & $\begin{array}{l}\text { Route: oral } \\
\text { Treatment: donepezil started at } 5 \mathrm{mg} \text { once daily for } 6 \text { weeks and increased to } 10 \mathrm{mg} \text { daily } \\
\text { for } 4 \text { weeks if tolerated }\end{array}$ \\
\hline Outcomes & $\begin{array}{l}\text { Primary outcome measures: mini-mental state examination (MMSE), the clinician's in- } \\
\text { terview based global impression of change (CIBIC+), the motor subscale of the unified } \\
\text { Parkinson's disease rating scale (UPDRS) } \\
\text { Secondary measures: Neuropsychiatric Inventory (NPI) and the severity of parkinsonism } \\
\text { (rated by patient and informer) }\end{array}$ \\
\hline Notes & Details of secondary outcome measures are currently unpublished \\
\hline
\end{tabular}

\section{Risk of bias}

\begin{tabular}{l|l|l}
\hline Bias & Authors' judgement & Support for judgement \\
\hline $\begin{array}{l}\text { Random sequence generation (selection } \\
\text { bias) }\end{array}$ & Low risk & $\begin{array}{l}\text { Quote: "a randomisation list was computer } \\
\text { generated according to a random block de- } \\
\text { sign" }\end{array}$ \\
\hline Allocation concealment (selection bias) & Low risk & $\begin{array}{l}\text { Quote: "the principal investigator was } \\
\text { given a sealed envelope containing the indi- } \\
\text { vidual treatment regimens of each patient" }\end{array}$ \\
\hline $\begin{array}{l}\text { Blinding (performance bias and detection } \\
\text { bias) } \\
\text { All outcomes }\end{array}$ & Low risk & $\begin{array}{l}\text { 'The initial dose was donepezil } 5 \text { mg or } \\
\text { identically appearing placebo tablets taken } \\
\text { once a day in the evening. The dose was }\end{array}$ \\
\hline
\end{tabular}




\begin{tabular}{l|l|l}
$\begin{array}{l}\text { Incomplete outcome data (attrition bias) } \\
\text { All outcomes }\end{array}$ & High risk & $\begin{array}{l}\text { Imputation of missing data using LOCF. } \\
\text { Too small to be able to say whether there } \\
\text { was differential dropout in drug arm. The } \\
\text { lack of a published behavioural outcome } \\
\text { increases the risk that there is selective re- } \\
\text { porting bias }\end{array}$ \\
\hline Other bias & High risk & $\begin{array}{l}\text { Small pilot studies such as this are inher- } \\
\text { ently at high risk of bias }\end{array}$
\end{tabular}

\section{Dubois 2007}

Methods

Randomised, multi-centre, double-blind, placebo-controlled, 3-arm parallel group Duration: 24 weeks

\begin{tabular}{ll}
\hline Participants & Countries: Details not available \\
& No. of centres: Details not available \\
& Diagnosis: PD by UK Brain Bank Criteria AND dementia by DSM-IV \\
Inclusions: Mild-moderately severe dementia , MMSE 10-26, present at least 1 year after \\
onset of PD \\
Exclusions: Details not available \\
Number of patients: 550 (377 on active treatment) \\
\hline Interventions & Route: oral \\
& Treatment: donepezil $5 \mathrm{mg}$ or $10 \mathrm{mg}$ for 24 weeks \\
\hline
\end{tabular}

Outcomes

Primary outcome measures: Alzheimer's Disease Assessment Scale - Cognitive subscale (ADAS-Cog); Alzheimer's Disease Cooperative Study - Clinician's Global Impression of Change (ADCS-CGIC)

Secondary outcome measures: executive function tests, working memory, attention and visuospatial function tests

$\begin{array}{ll}\text { Notes } & \text { Tolerability and safety assessed } \\ & \text { Treatment-related motor impairment assessed by motor subscale of UPDSRS } \\ \text { Treatment-by-country interaction investigated }\end{array}$

Risk of bias

\begin{tabular}{lll}
\hline Bias & Authors' judgement & Support for judgement \\
\hline $\begin{array}{l}\text { Random sequence generation (selection } \\
\text { bias) }\end{array}$ & Unclear risk & $\begin{array}{l}\text { No details of randomisation process avail- } \\
\text { able }\end{array}$ \\
\hline Allocation concealment (selection bias) & Unclear risk & No details of available
\end{tabular}


Dubois 2007 (Continued)

\begin{tabular}{|c|c|c|}
\hline $\begin{array}{l}\text { Blinding (performance bias and detection } \\
\text { bias) } \\
\text { All outcomes }\end{array}$ & Unclear risk & No details available \\
\hline $\begin{array}{l}\text { Incomplete outcome data (attrition bias) } \\
\text { All outcomes }\end{array}$ & High risk & $\begin{array}{l}\text { Only available as a poster. High risk of se- } \\
\text { lective reporting of data, especially given } \\
\text { that remains unpublished }\end{array}$ \\
\hline
\end{tabular}

Emre 2004

Methods

Randomised, multicenter, double-blind, placebo-controlled.

Duration: 24 weeks

Countries: Austria, Belgium, Canada, France, Germany, Italy, Holland, Norway, Portu-
gal, Spain, Turkey, UK.
No. of centres: not stated.
Diagnosis: PD by UK Parkinson's Disease Society Brain Bank criteria; Dementia by
DSM-IV (dementia due to Parkinson's disease code 294.1)
Inclusions: MMSE 10 to 24; onset of symptoms of dementia more than 2 years after
diagnosis of PD; regular caregiver.
Exclusions: primary neurodegenerative disease other than PD or dementia; history ma-
jor depression; presence of active uncontrolled seizure disorder; disability or unstable
disease unrelated to PD; hypersensitivity rivastigmine or similar drugs; use cholinesterase
inhibitor or anticholinergic drug.
Number of patients (Randomised/ITT/completers): rivastigmine: $362 / 329 / 263 ;$
placebo:179/161/147

Interventions $\quad$ Route: oral

Treatment: rivastigmine commenced at $1.5 \mathrm{mg}$ twice daily and increased according to tolerability by $3 \mathrm{mg}$ daily at intervals of at least 4 weeks over a 16 week period

Outcomes

Primary outcome measures: Intention to treat analysis with LOCF

Alzheimer's Disease Assessment Scale - Cognitive sub-scale (ADAS-Cog); Alzheimer's Disease Cooperative Study - Clinician's Global Impression of Change (ADCS-CGIC) Secondary measures: Mini-Mental State Examination (MMSE); Alzheimer's Disease Cooperative Study - Activities of Daily Living (ADCS-ADL); Neuropsychiatric Inventory (NPI); Cognitive Drug Research (CDR) Computerized Assessment System power of attention tests; Delis-Kaplan Executive Function System (D-KEFS) Verbal Fluency test; Ten Point Clock-Drawing test; Unified Parkinson's Disease Rating Scale (UPDRS)

Notes

Risk of bias

Bias

Authors' judgement

Support for judgement 
Emre 2004 (Continued)

Random sequence generation (selection Low risk bias)
Quote: “automated random assignment of treatment was performed with the use of a validated system, managed by Novartis Drug Supply Managment"

Blinding (performance bias and detection Low risk bias)

All outcomes

Incomplete outcome data (attrition bias) Low risk

All outcomes
Intention-to-treat analysis with LOCF. About half those who discontinued drug continued to attend for ITT evaluations, thereby reducing the attrition bias towards a positive effect of drug which would be associated with the greater discontinuation rate amongst those taking drug which occurred

Other bias Low risk
Comment: The study appears to be free of other sources of bias

\section{Leroi 2004}

Methods

Participants
Randomized, multicenter, double-blind, placebo-controlled.

Duration: 18 weeks

\section{Country: USA}

No. of centres: 2

Diagnosis: PD by UK Parkinson's Disease Brain Bank Criteria AND either dementia or cognitive impairment secondary to PD by DSM IV

Inclusions: on stable regimens of anti-Parkinsonian medications.

Exclusions: MMSE $<10$, substance abuse or dependence (by DSM IV criteria), severe cardiac disease, severe renal disease, severe vascular disease, non-ambulatory, known inability to tolerate donepezil

Number of patient: 16 ( 9 on active treatment)

Interventions

Route: oral

Treatment: donepezil started at $2.5 \mathrm{mg}$ daily for 5 days then $5 \mathrm{mg}$ daily for 30 days then $7.5 \mathrm{mg}$ daily for 5 days then $10 \mathrm{mg}$ daily for 91 days (total 18 weeks), study medication could be reduced in $2.5 \mathrm{mg}$ decrements in response to adverse effects

Outcomes

LOCF analysis. Primary outcome measure: Mini Mental State Examination (MMSE); Dementia Rating Scale (DRS) - total score, attention subscore, initiation-perseveration subscore, conceptualisation subscore, memory subscore; Brief Test of Attention (BTA) ;Trail Making Test-Part A and B (TMT-A and TMT-B); Verbal Fluency; Hopkins Verbal Learning Test-Revised (HVLT); Developmental Test of Visual-motor Integration (VMI) Secondary measures: Neuropsychiatric Inventory (NPI); Cornell Scale for Depression in Dementia (CSDD); UPDRS-Activities of Daily Living (ADL) and Complications of 
Leroi 2004 (Continued)

Therapy subscales

Safety measures: Unified Parkinson's Disease Rating Scale (UPDRS) motor subscale;

Hoehn and Yahr stage

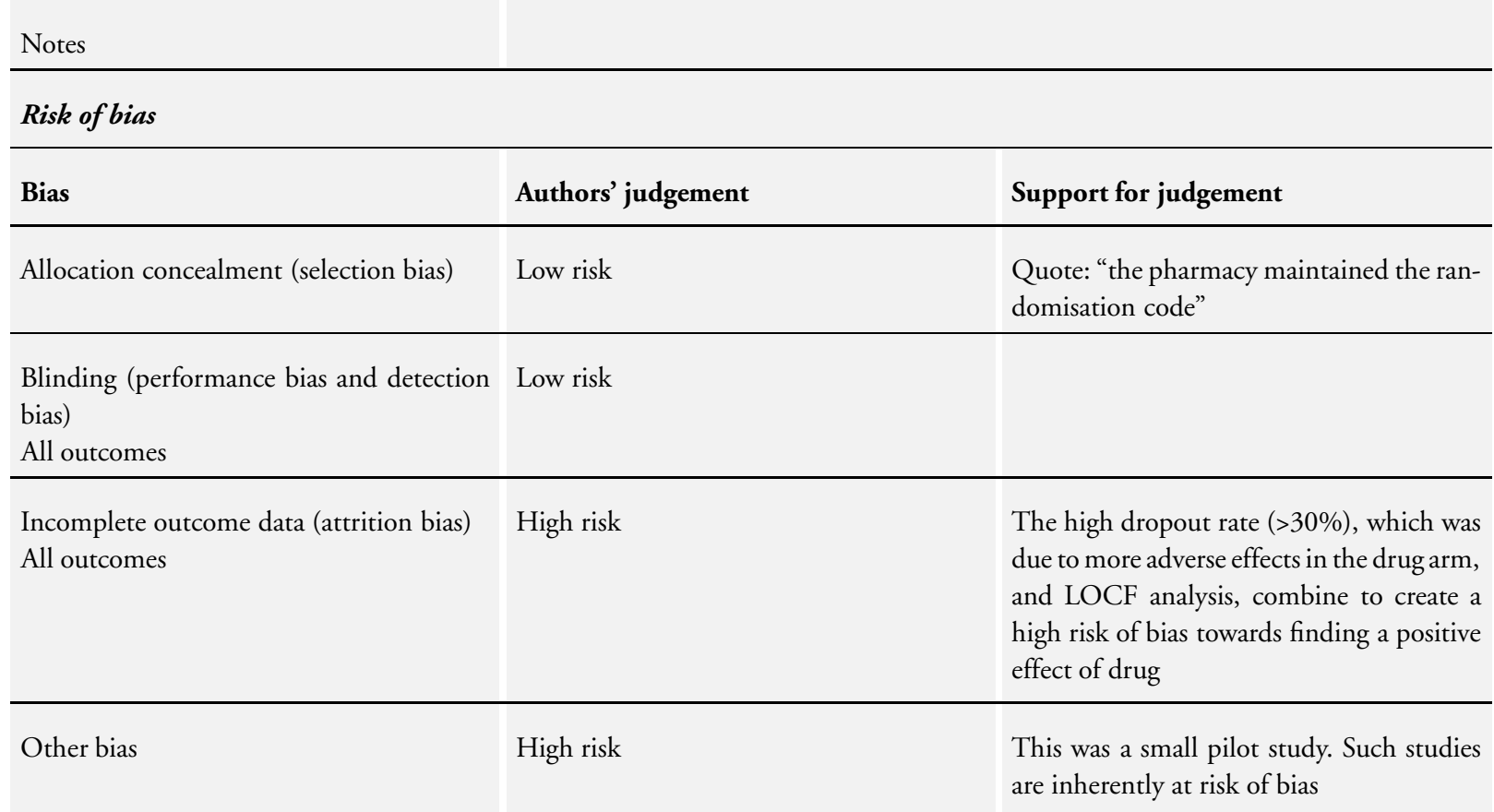

\section{McKeith 2000}

Methods

Randomised, multicenter, double-blind, placebo-controlled.

Duration: 23 weeks - 20 weeks treatment followed by 3 weeks 'rest'

\begin{tabular}{ll} 
Participants & $\begin{array}{l}\text { Countries: Spain, UK and Italy } \\
\text { No. of centres: details not available } \\
\text { Diagnosis: clinical diagnosis of probable Lewy body dementia } \\
\text { Inclusion: MMSE }>9 \text {, regular caregiver } \\
\text { Exclusion: severe extrapyramidal symptoms, asthma, taking neuroleptics, anticholiner- } \\
\text { gics, selegiline or similar drugs } \\
\text { Number of patients (Randomised/ITT/Completers): RVS: } 59 / \mathrm{n}_{1} / 41 \text { Placebo: } 61 / \mathrm{n}_{2} / 51 \\
\left(\mathrm{n}_{1}+\mathrm{n}_{2}=117\right)\end{array}$ \\
\hline Interventions & $\begin{array}{l}\text { Route: oral } \\
\text { Treatment: rivastigmine started at } 1.5 \text { mg twice daily, titrated to } 6 \mathrm{mg} \text { twice daily (or } \\
\text { maximum tolerated) over } 8 \text { weeks maximum }\end{array}$ \\
\hline Outcomes & $\begin{array}{l}\text { ITT Neuropsychiatric Inventory, } 10 \text { and } 4 \text { item versions (NPI-10 \& NPI-4); speed of } \\
\text { response to selected tests; Clinician's Global Impression of Change (ADCS-CGIC); Mini } \\
\text { Mental State Examination (MMSE); Unified Parkinson's Disease Rating Scale (UPDRS) }\end{array}$ \\
\hline
\end{tabular}


McKeith 2000 (Continued)

\begin{tabular}{|c|c|c|}
\hline Notes & \multicolumn{2}{|c|}{$\begin{array}{l}\text { Data on speed of response was not used in this Cochrane review, as we viewed it as a } \\
\text { proxy measure rather than a direct measure of a clinically important feature of DLB. } \\
\text { We were unable to include the UPDRS, as data was not presented in the published paper }\end{array}$} \\
\hline \multicolumn{3}{|l|}{ Risk of bias } \\
\hline Bias & Authors' judgement & Support for judgement \\
\hline $\begin{array}{l}\text { Random sequence generation (selection } \\
\text { bias) }\end{array}$ & Low risk & $\begin{array}{l}\text { Quote: "randomisation list was computer } \\
\text { generated with a proprietary computer ap- } \\
\text { plication, according to a randomised block } \\
\text { design" }\end{array}$ \\
\hline Allocation concealment (selection bias) & Low risk & $\begin{array}{l}\text { Quote: "envelopes were to be opened only } \\
\text { in case of emergency and were collected af- } \\
\text { ter unblinding and verified for code breaks" }\end{array}$ \\
\hline
\end{tabular}

Blinding (performance bias and detection Low risk

bias)

All outcomes

\begin{tabular}{l|l|l}
\hline $\begin{array}{l}\text { Incomplete outcome data (attrition bias) } \\
\text { All outcomes }\end{array}$ & Unclear risk & $\begin{array}{l}\text { The presentation of ITT, LOCF and OC } \\
\text { data is commendable. However, it is not } \\
\text { reported how many of those in the ITT } \\
\text { dataset were providing data for the final } \\
\text { time point despite having discontinued } \\
\text { medication and whether there was an im- } \\
\text { balance in this. It is not clear whether out- } \\
\text { come reporting was selective }\end{array}$ \\
\hline Other bias & Low risk & $\begin{array}{l}\text { Comment: The study appears to be free of } \\
\text { other sources of bias }\end{array}$ \\
\hline
\end{tabular}

\section{Ravina 2005}

\begin{tabular}{ll} 
Methods & $\begin{array}{l}\text { Randomized, multicenter, double-blind, crossover, placebo-controlled. } \\
\text { Duration: } 10 \text { weeks }\end{array}$ \\
\hline Participants & Country: USA \\
No. of centres: 4 \\
Diagnosis: PD by Movement Disorders Society Scientific issues Committee Parkinsonian \\
disorders (diagnosis made by movement disorder specialists) \\
Inclusions: age $>40$ years, mild-moderate dementia according to DSM IV criteria for \\
dementia AND MMSE $17-26$ \\
Exclusions: clinical diagnosis of DLB, other causes of dementia (e.g. stoke), use of \\
cholinergic or anticholinergic agents except amantadine or tolterodine within 2 weeks \\
before screening, medical conditions or uncontrolled psychosis which were thought by \\
investigator to interfere with the safe conduct of study, pregnancy or lactation.
\end{tabular}

Cholinesterase inhibitors for dementia with Lewy bodies, Parkinson's disease dementia and cognitive impairment in Parkinson's disease 23 (Review) 
Ravina 2005 (Continued)

Number of patients: 22

\begin{tabular}{ll}
\hline Interventions & $\begin{array}{l}\text { Route: oral } \\
\text { Treatment: donepezil started at } 5 \mathrm{mg} \text { once daily and increased according to tolerability } \\
\text { to donepezil } 5 \mathrm{mg} \text { twice daily after } 3 \text { weeks, then continued at that dose (if tolerated, } \\
\text { otherwise reduced back to } 5 \mathrm{mg} \text { once daily) for } 6 \text { weeks }\end{array}$ \\
\hline Outcomes & $\begin{array}{l}\text { Primary outcome measure: Alzheimer's Disease Assessment Scale-Cognitive Subscale } \\
\text { (ADAS-Cog) } \\
\text { Secondary measures: Mini Mental State Examination (MMSE); Mattis Dementia Rating } \\
\text { Scale (MDRS); Brief Psychiatric Rating Scale (BPRS); Unified Parkinson's Disease Rating } \\
\text { Scale (UPDRS); Clinician's Global Impression of Change (ADCS-CGIC) }\end{array}$ \\
\hline
\end{tabular}

Notes

Data from first 10 week period was analysed for this review

BPRS is a measure of psychosis

\section{Risk of bias}

\begin{tabular}{|c|c|c|}
\hline Bias & Authors' judgement & Support for judgement \\
\hline $\begin{array}{l}\text { Random sequence generation (selection } \\
\text { bias) }\end{array}$ & Unclear risk & $\begin{array}{l}\text { 'Drug distribution to the sites and ran- } \\
\text { domisation were performed by the Univer- } \\
\text { sity of Pennsylvania } \\
\text { Investigational Drug Services Unit. Sub- } \\
\text { jects were randomised in blocks of four } \\
\text { to receive either donepezil in period I and } \\
\text { placebo in period II or placebo in period I } \\
\text { and donepezil in period II.' }\end{array}$ \\
\hline Allocation concealment (selection bias) & Low risk & \\
\hline $\begin{array}{l}\text { Blinding (performance bias and detection } \\
\text { bias) } \\
\text { All outcomes }\end{array}$ & Low risk & 'matching placebo' \\
\hline $\begin{array}{l}\text { Incomplete outcome data (attrition bias) } \\
\text { All outcomes }\end{array}$ & High risk & LOCF imputation of missing data \\
\hline Other bias & High risk & $\begin{array}{l}\text { This was a very small study. Such studies } \\
\text { are at inherent risk of bias }\end{array}$ \\
\hline
\end{tabular}


Characteristics of excluded studies [ordered by study ID]

\begin{tabular}{|c|c|}
\hline Study & Reason for exclusion \\
\hline Aarsland 2002 & Open label study \\
\hline Adler 2011 & Non-interventional trial \\
\hline Anand 2000 & Conference presentation. Review, not a clinical trial \\
\hline Barone 2008 & Only hyperhomocysteinemic Parkinson's disease dementia patients included \\
\hline Barone 2010 & Open label study \\
\hline Bergman 2002 & Open label study \\
\hline Bergman 2003 & Open label study; trial of people with Alzheimer's disease, not Parkinson's \\
\hline Beversdorf 2004 & $\begin{array}{l}\text { Data kindly provided by the author, judged unsuitable for meta-analysis as a small double cross-over study } \\
\text { without a wash-out period and no carry-over effect analysis }\end{array}$ \\
\hline Brashear 2004 & Data limited, details not available \\
\hline Chung 2010 & Trial of people with Parkinson's disease with advanced postural instability \\
\hline Cummings 2010 & Trial of people with Alzheimer's disease, not Parkinson's \\
\hline De Deyn 2011 & Open label study \\
\hline Fabbrini 2002 & Open label study \\
\hline Fogelson 2003 & Open label study; non-standard outcome measures \\
\hline Foy 2000 & Diagnostic criteria outside specification \\
\hline Fujita 2010 & Case report \\
\hline Giladi 2003 & Open label study \\
\hline Gustavsson 2009 & Open label study \\
\hline Hutchinson 1996 & Open label study \\
\hline Korczyn 2001 & Open label study \\
\hline Lanctot 2000 & Case series \\
\hline Linsarazo 2005 & Open label study \\
\hline
\end{tabular}

Cholinesterase inhibitors for dementia with Lewy bodies, Parkinson's disease dementia and cognitive impairment in Parkinson's disease 25

(Review)

Copyright () 2012 The Cochrane Collaboration. Published by John Wiley \& Sons, Ltd. 
(Continued)

\begin{tabular}{|c|c|}
\hline Litvinenko 2008 & Open label study \\
\hline McKeith 2000a & Open label exploratory trial; 20 weeks active treatment then 6 weeks of withdrawal \\
\hline McLaren 2003 & Open label study \\
\hline Minett 2003 & Open label study \\
\hline Mori 2006 & Open label study \\
\hline Olin 2010a & Open label study, rivastigmine and memantine used \\
\hline Pakrasi 2006 & Open label study \\
\hline Reading 2001 & Open label study \\
\hline Rektorova 2004 & Open label study \\
\hline Rosengarten 2010 & Investigation of pathophysiological changes \\
\hline Samuel 2000 & Lewy body dementia patients compared with Alzheimer's disease patients regarding response to donepezil \\
\hline Satoh 2010 & Investigation of pathophysiological changes \\
\hline Thomas 2005 & Open label study \\
\hline Touchon 2006a & Retrospective study \\
\hline Touchon $2006 b$ & as Touchon 2006a \\
\hline Van Laar 2001 & Open label study \\
\hline Vasile 2010a & Comparative efficacy of cholinesterase inhibitors, no placebo group \\
\hline Vasile 2010b & Comparative efficacy of cholinesterase inhibitors, no placebo group \\
\hline Walker 2000b & Investigation of pathophysiological changes \\
\hline Werber 2001 & Open label study \\
\hline Wilcock 2000 & Project abandoned \\
\hline
\end{tabular}




\section{Characteristics of ongoing studies [ordered by study ID]}

\section{Anon 2004a}

\begin{tabular}{|c|c|}
\hline Trial name or title & $\begin{array}{l}\text { Donepezil for dementia in Parkinson's disease: A randomised double blinded placebo controlled crossover } \\
\text { trial }\end{array}$ \\
\hline Methods & RCT \\
\hline Participants & $\begin{array}{l}\mathrm{N}=28 \\
\text { Country = USA } \\
\text { Duration = } 26 \text { weeks }\end{array}$ \\
\hline Interventions & Donepezil + Placebos \\
\hline Outcomes & $\begin{array}{l}\text {-ADAS/cog } \\
\text {-cognitive function } \\
\text {-activities of daily living } \\
\text {-mood } \\
\text {-quality of life } \\
\text {-side effects } \\
\text {-motor performance }\end{array}$ \\
\hline Starting date & February 2002 \\
\hline \multicolumn{2}{|l|}{ Contact information } \\
\hline Notes & Study ID numbers 020115; 02-N-0115//NLM identifier NCT00030979 \\
\hline
\end{tabular}

Anon 2007a

\begin{tabular}{ll} 
Trial name or title & Double-blind study of E2020 in patients with dementia with Lewy bodies - Phase II \\
\hline Methods & RCT \\
\hline Participants & $\begin{array}{l}\mathrm{N}=160 \\
\text { Country }=\text { Japan } \\
\text { Duration }=12 \text { weeks }\end{array}$ \\
\hline Interventions & Donepezil (E2020), Dosage of drug, Placebo \\
\hline Outcomes & $\begin{array}{l}\text { Primary outcome measures: Cognitive function, psychiatric symptoms, and global clinical function, burden } \\
\text { on caregiver at 12 weeks }\end{array}$ \\
\hline Starting date & November 2007 \\
\hline Contact information & \begin{tabular}{l} 
Study ID(s) and Acronym(s): NCT00543855 // E2020-J081-431 \\
\hline Notes
\end{tabular}
\end{tabular}

Cholinesterase inhibitors for dementia with Lewy bodies, Parkinson's disease dementia and cognitive impairment in Parkinson's disease 27 (Review) 
Anon 2011

\begin{tabular}{ll} 
Trial name or title & $\begin{array}{l}\text { A study of E2020 in patients with dementia with Lewy bodies (DLB), followed by a long-term extension } \\
\text { phase - Phase III }\end{array}$ \\
\hline Methods & RTC \\
\hline Participants & $\begin{array}{l}\mathrm{N}=141 \\
\text { Country }=\text { Japan } \\
\text { Duration }=52 \text { weeks }\end{array}$ \\
\hline Interventions & Donepezil (E2020), Dosage of drug, Placebo \\
\hline Outcomes & $\begin{array}{l}\text { Primary Outcome Measures: Change from baseline in Mini Mental State Examination and Neuropsychiatric } \\
\text { Inventory after 12 weeks }\end{array}$ \\
\hline Starting date & February 2011 \\
\hline Contact information & \\
\hline Notes & Study ID(s) and Acronym(s): NCT01278407 // E2020-J081-341 \\
\hline
\end{tabular}

\section{Burn 2009}

\begin{tabular}{|c|c|}
\hline Trial name or title & $\begin{array}{l}\text { Multi-centre UK study of the acetylcholinesterase inhibitor donepezil in early dementia associated with } \\
\text { Parkinson's disease (MUSTARDD-PD) }\end{array}$ \\
\hline Methods & $\begin{array}{l}\text { - RCT } \\
\text { - 1. Donepezil: Experimental - } 5 \mathrm{mg} \text { of Donepezil for the first } 8 \text { weeks raising to } 10 \mathrm{mg} \text { thereafter if patient } \\
\text { adjusted to } 5 \mathrm{mg} \text { dose. } 10 \mathrm{mg} \text { does continues for the remainder of the study; } 2 \text {. Placebo: Placebo Comparator } \\
\text { - Patient commences medication to match appearance of } 5 \mathrm{mg} \text { donepezil for first } 8 \text { weeks then } 10 \mathrm{mg} \text { for the } \\
\text { remainder of the study }\end{array}$ \\
\hline Participants & $\begin{array}{l}\mathrm{N}=500 \\
\text { Country = UK } \\
\text { Duration }=24 \text { months }\end{array}$ \\
\hline Interventions & Donepezil, Placebo \\
\hline Outcomes & $\begin{array}{l}\text { Primary Outcome Measures: To demonstrate the superiority of donepezil over placebo in improving cognitive } \\
\text { function, neuropsychiatric burden and functional ability in people with Parkinson's disease and mild dementia } \\
\text { after } 24 \text { months of treatment } \\
\text { Secondary Outcome Measures: To demonstrate the superiority of donepezil over placebo in improving patient } \\
\text { and carer quality of life and to establish the cost-effectiveness of donepezil }\end{array}$ \\
\hline Starting date & March 2010 \\
\hline Contact information & \\
\hline Notes & Study ID(s) and Acronym(s): NCT01014858 // MUSTARDD-PD // 5137 // 08/13/14 \\
\hline
\end{tabular}

Cholinesterase inhibitors for dementia with Lewy bodies, Parkinson's disease dementia and cognitive impairment in Parkinson's disease 28 (Review) 
Kurlan 2003

\begin{tabular}{ll}
\hline Trial name or title & Treatment of agitation/psychosis in dementia/parkinsonism \\
\hline Methods & $\begin{array}{l}\text { N = Unknown } \\
\text { Country }=\text { USA } \\
\text { Duration }=\text { Unknown }\end{array}$ \\
\hline Participants & Donepezil, Quetiapine, Dosage of drug \\
\hline Interventions & Unknown \\
\hline Outcomes & $\begin{array}{l}\text { Kurlan R Treatment of agitation/psychosis in dementia/parkinsonism Alzheimer's Disease Education and } \\
\text { Referral Center (ADEAR) 2003 }\end{array}$ \\
\hline Contact information date & \\
\hline Notes & \\
\hline
\end{tabular}

\section{Marion 2003}

\begin{tabular}{ll} 
Trial name or title & $\begin{array}{l}\text { An open 24 week prospective, randomised, double-blind placebo controlled parallel group study of efficacy, } \\
\text { tolerability and safety of 3-12mg/day of Exelon and Exelon (rivastigmine) capsules in patients with Parkinson's } \\
\text { disease dementia }\end{array}$ \\
\hline Methods & $\begin{array}{l}\mathrm{N}=10 \\
\text { Country }=\mathrm{UK} \\
\text { Duration }=24 \text { weeks }\end{array}$ \\
\hline Participants & Rivastigmine + Dosage of Drug + Placebos \\
\hline Interventions & Unclear \\
\hline Outcomes & \\
\hline Starting date & Marie-Helene.Marion@stgeorges.nhs.uk \\
\hline Contact information & \\
\hline Notes &
\end{tabular}


DATA AND ANALYSES

\section{Comparison 1. Global assessment}

\begin{tabular}{lcccc} 
Outcome or subgroup title & $\begin{array}{c}\text { No. of } \\
\text { studies }\end{array}$ & $\begin{array}{c}\text { No. of } \\
\text { participants }\end{array}$ & Statistical method & Effect size \\
\hline $\begin{array}{l}\text { 1 Alzheimer's Disease Cooperative } \\
\text { Study - Clinician's Global }\end{array}$ & 3 & 556 & Std. Mean Difference (IV, Fixed, 95\% CI) & $-0.38[-0.56,-0.20]$ \\
$\begin{array}{l}\text { Impression of Change (ADCS- } \\
\text { CGIC) }\end{array}$ & 3 & 785 & Odds Ratio (M-H, Random, 95\% CI) & $2.26[1.04,4.91]$ \\
$\begin{array}{l}2 \text { Clinical Global Responder - at } \\
\text { least minimal improvement }\end{array}$ & 3 & & & \\
\hline
\end{tabular}

Comparison 2. Cognitive function

\begin{tabular}{|c|c|c|c|c|}
\hline Outcome or subgroup title & $\begin{array}{l}\text { No. of } \\
\text { studies }\end{array}$ & $\begin{array}{c}\text { No. of } \\
\text { participants }\end{array}$ & Statistical method & Effect size \\
\hline 1 Mini Mental State Examination & 5 & 699 & Mean Difference (IV, Fixed, 95\% CI) & $1.08[0.50,1.66]$ \\
\hline $\begin{array}{l}2 \text { Alzheimer's Disease Assessment } \\
\text { Scale (ADAS-cog) }\end{array}$ & 3 & 1078 & Mean Difference (IV, Fixed, 95\% CI) & $-2.72[-3.61,-1.83]$ \\
\hline $\begin{array}{l}3 \text { Combined: MMSE or } \\
\text { ADASCog }\end{array}$ & 6 & 1249 & Std. Mean Difference (IV, Random, 95\% CI) & $0.34[0.23,0.46]$ \\
\hline $\begin{array}{l}4 \text { Mattis Dementia Rating Scale } \\
\text { (MDRS) }\end{array}$ & 3 & 82 & Mean Difference (IV, Fixed, 95\% CI) & $3.70[-1.13,8.54]$ \\
\hline $\begin{array}{l}5 \text { Cognitive Drug Research (CDR) } \\
\text { computerised assessment } \\
\text { system power of attention }\end{array}$ & 1 & 486 & Mean Difference (IV, Fixed, 95\% CI) & $\begin{array}{l}-173.7[-471.23 \\
123.83]\end{array}$ \\
\hline $\begin{array}{l}6 \text { Delis-Kaplan Executive Function } \\
\text { System (D-KEFS) }\end{array}$ & 1 & 402 & Mean Difference (IV, Fixed, 95\% CI) & $2.8[1.47,4.13]$ \\
\hline 7 Ten Point Clock Drawing Test & 1 & 79 & Mean Difference (IV, Fixed, 95\% CI) & $1.1[-0.01,2.21]$ \\
\hline 8 Brief Test of Attention (BTA) & 1 & 16 & Mean Difference (IV, Fixed, 95\% CI) & $1.65[-0.82,4.12]$ \\
\hline 9 Trail Making Test (TMT) A & 1 & 16 & Mean Difference (IV, Fixed, 95\% CI) & $\begin{array}{l}-71.68[-108.44,- \\
34.92]\end{array}$ \\
\hline 10 Trail Making Test (TMT) B & 1 & 16 & Mean Difference (IV, Fixed, 95\% CI) & $\begin{array}{l}-87.24[-202.89,28 . \\
41]\end{array}$ \\
\hline 11 Verbal Fluency Test & 1 & 16 & Mean Difference (IV, Fixed, 95\% CI) & $6.63[-2.33,15.59]$ \\
\hline 12 Hopkins Verbal Learning Test & 1 & 16 & Mean Difference (IV, Fixed, 95\% CI) & $1.72[-2.93,6.37]$ \\
\hline $\begin{array}{l}13 \text { Developmental Test of Visual- } \\
\text { Motor Integration (VMI) }\end{array}$ & 1 & 16 & Mean Difference (IV, Fixed, 95\% CI) & $0.03[-3.28,3.34]$ \\
\hline
\end{tabular}

Cholinesterase inhibitors for dementia with Lewy bodies, Parkinson's disease dementia and cognitive impairment in Parkinson's disease 30 (Review)

Copyright () 2012 The Cochrane Collaboration. Published by John Wiley \& Sons, Ltd. 


\begin{tabular}{|c|c|c|c|c|}
\hline Outcome or subgroup title & $\begin{array}{l}\text { No. of } \\
\text { studies }\end{array}$ & $\begin{array}{c}\text { No. of } \\
\text { participants }\end{array}$ & Statistical method & Effect size \\
\hline $\begin{array}{l}1 \text { 12-item Neuropsychiatric } \\
\text { Inventory (NPI-12) }\end{array}$ & 1 & 16 & Mean Difference (IV, Fixed, 95\% CI) & $-3.3[-13.75,7.15]$ \\
\hline $\begin{array}{l}2 \text { 10-item Neuropsychiatric } \\
\text { Inventory (NPI-10) }\end{array}$ & 2 & 620 & Mean Difference (IV, Fixed, 95\% CI) & $-2.18[-3.95,-0.40]$ \\
\hline $\begin{array}{l}3 \text { 4-item Neuropsychiatric } \\
\text { Inventory (NPI-4) }\end{array}$ & 1 & 120 & Mean Difference (IV, Fixed, 95\% CI) & $-1.66[-4.34,1.02]$ \\
\hline 4 Brief Psychiatric Rating Scale & 1 & 38 & Mean Difference (IV, Fixed, 95\% CI) & $-0.30[-5.89,5.29]$ \\
\hline 5 Combined & 4 & 674 & Std. Mean Difference (IV, Fixed, 95\% CI) & $-0.20[-0.36,-0.04]$ \\
\hline $\begin{array}{l}5.1 \text { 12-item Neuropsychiatric } \\
\text { Inventory (NPI-12) }\end{array}$ & 1 & 16 & Std. Mean Difference (IV, Fixed, 95\% CI) & $-0.29[-1.29,0.70]$ \\
\hline $\begin{array}{l}5.2 \text { 10-item Neuropsychiatric } \\
\text { Inventory (NPI-10) }\end{array}$ & 2 & 620 & Std. Mean Difference (IV, Fixed, 95\% CI) & $-0.21[-0.37,-0.04]$ \\
\hline $\begin{array}{l}\text { 5.3 Brief Psychiatric Rating } \\
\text { Scale }\end{array}$ & 1 & 38 & Std. Mean Difference (IV, Fixed, 95\% CI) & $-0.03[-0.67,0.60]$ \\
\hline
\end{tabular}

\section{Comparison 4. Activities of daily living}

\begin{tabular}{|c|c|c|c|c|}
\hline Outcome or subgroup title & $\begin{array}{l}\text { No. of } \\
\text { studies }\end{array}$ & $\begin{array}{c}\text { No. of } \\
\text { participants }\end{array}$ & Statistical method & Effect size \\
\hline $\begin{array}{l}1 \text { Alzheimer's Disease Cooperative } \\
\text { Study - Activities of Daily } \\
\text { Living (ADCS-ADL) }\end{array}$ & 1 & 498 & Mean Difference (IV, Fixed, 95\% CI) & $2.5[0.43,4.57]$ \\
\hline $\begin{array}{c}2 \text { Unified Parkinson's Disease } \\
\text { Rating Scale (UPDRS) - } \\
\text { Activities of Daily Living }\end{array}$ & 1 & 16 & Mean Difference (IV, Fixed, 95\% CI) & $0.84[-6.24,7.92]$ \\
\hline 3 Combined & 2 & 514 & Std. Mean Difference (IV, Fixed, 95\% CI) & $-0.20[-0.38,-0.02]$ \\
\hline $\begin{array}{l}\text { 3.1 Alzheimer's Disease } \\
\text { Cooperative Study - Activities } \\
\text { of Daily Living (ADCS-ADL) }\end{array}$ & 1 & 498 & Std. Mean Difference (IV, Fixed, 95\% CI) & $-0.21[-0.40,-0.02]$ \\
\hline $\begin{array}{l}\text { 3.2 Unified Parkinson's } \\
\text { Disease Rating Scale (UPDRS) } \\
\text { - Activities of Daily Living }\end{array}$ & 1 & 16 & Std. Mean Difference (IV, Fixed, 95\% CI) & $0.11[-0.88,1.10]$ \\
\hline
\end{tabular}

Cholinesterase inhibitors for dementia with Lewy bodies, Parkinson's disease dementia and cognitive impairment in Parkinson's disease 3 I (Review) 
Comparison 5. Safety and tolerability

\begin{tabular}{lcclc} 
Outcome or subgroup title & $\begin{array}{c}\text { No. of } \\
\text { studies }\end{array}$ & $\begin{array}{c}\text { No. of } \\
\text { participants }\end{array}$ & Statistical method & Effect size \\
\hline 1 Dropouts & 5 & 744 & Odds Ratio (M-H, Fixed, 95\% CI) & $1.94[1.33,2.84]$ \\
2 Dropouts due to Adverse Events & 3 & 677 & Odds Ratio (M-H, Fixed, 95\% CI) & $2.12[1.27,3.55]$ \\
3 Adverse Events & 6 & 1294 & Odds Ratio (M-H, Fixed, 95\% CI) & $1.64[1.26,2.15]$ \\
4 Severe Adverse Events & 2 & 146 & Odds Ratio (M-H, Fixed, 95\% CI) & $1.60[0.68,3.81]$ \\
5 Parkinsonian symptoms reported & 2 & 1091 & Odds Ratio (M-H, Fixed, 95\% CI) & $1.88[1.28,2.75]$ \\
$\quad$ as adverse effects & 2 & 1091 & Odds Ratio (M-H, Fixed, 95\% CI) & $2.71[1.44,5.09]$ \\
6 Tremor & 2 & 1091 & Odds Ratio (M-H, Fixed, 95\% CI) & $1.29[0.72,2.33]$ \\
7 Falls & 2 & 1091 & Odds Ratio (M-H, Fixed, 95\% CI) & $0.64[0.40,1.02]$ \\
8 Hallucinations & 3 & 122 & Std. Mean Difference (IV, Fixed, 95\% CI) & $-0.07[-0.42,0.29]$ \\
9 Unified Parkinson's Disease & & & & \\
$\quad$ Rating Scale (UPDRS) & 3 & 81 & Std. Mean Difference (IV, Fixed, 95\% CI) & $-0.05[-0.49,0.39]$ \\
$\quad$ 9.1 Motor & 1 & 41 & Std. Mean Difference (IV, Fixed, 95\% CI) & $-0.10[-0.72,0.51]$ \\
$\quad$ 9.2 Total & 5 & 744 & Odds Ratio (M-H, Fixed, 95\% CI) & $0.28[0.09,0.84]$ \\
10 Deaths & & & &
\end{tabular}

\section{ADDITIONAL TABLES}

Table 1. Effect of cholinesterase inhibitors on dementia with Lewy bodies, Parkinson's disease dementia and cognitive impairment in Parkinson's disease

\begin{tabular}{|c|c|c|c|c|}
\hline & $\begin{array}{l}\text { Dementia with Lewy } \\
\text { Bodies(DLB) }\end{array}$ & $\begin{array}{l}\text { Parkinson's Disease } \\
\text { with dementia (PDD) }\end{array}$ & $\begin{array}{l}\text { Parkinson's } \\
\text { Disease with dementia } \\
\text { (PDD) and cognitive } \\
\text { impairment in Parkin- } \\
\text { son's Disease (CIND- } \\
\text { PD) }\end{array}$ & $\begin{array}{l}\text { Pooled results for } \\
\text { DLB/PDD/CIND-PD }\end{array}$ \\
\hline Global Assessment & N/A & $\begin{array}{l}\text { Favours treatment } \\
(\mathrm{SMD}-0.38,95 \% \mathrm{CI}- \\
0.56,-0.24, \mathrm{P}<0.00001)\end{array}$ & N/A & N/A \\
\hline Cognitive Function & $\begin{array}{l}\text { No effect } \\
(S M D-0.29,95 \% \text { CI - } \\
0.65,0.07, P=0.12)\end{array}$ & $\begin{array}{l}\text { Favours treatment } \\
(\mathrm{SMD}-0.36,95 \% \mathrm{CI}- \\
0.48,-0.23, \mathrm{P}<0.00001)\end{array}$ & $\begin{array}{l}\text { Favours treatment } \\
(\mathrm{SMD}-0.36,95 \% \mathrm{CI}- \\
0.48,-0.23, \mathrm{P}<0.00001)\end{array}$ & $\begin{array}{l}\text { Favours treatment } \\
(\mathrm{SMD}-0.34,95 \% \mathrm{CI}- \\
0.46,-0.23, \mathrm{P}<0.00001)\end{array}$ \\
\hline $\begin{array}{l}\text { Behavioural } \\
\text { Disturbance }\end{array}$ & $\begin{array}{l}\text { No effect } \\
(\mathrm{SMD}-0.24,95 \% \mathrm{CI}- \\
0.60,0.12, \mathrm{P}=0.19)\end{array}$ & $\begin{array}{l}\text { Favours treatment } \\
(\mathrm{SMD}-0.18,95 \% \mathrm{CI}- \\
0.36,-0.01, \mathrm{P}=0.04)\end{array}$ & $\begin{array}{l}\text { Favours treatment } \\
(\mathrm{SMD}-0.19,95 \% \mathrm{CI}- \\
0.36,-0.01, \mathrm{P}=0.04)\end{array}$ & $\begin{array}{l}\text { Favours treatment } \\
(\mathrm{SMD}-0.20,95 \% \mathrm{CI}- \\
0.36,-0.04, \mathrm{P}=0.01)\end{array}$ \\
\hline $\begin{array}{l}\text { Activities of Daily Liv- } \\
\text { ing }\end{array}$ & N/A & $\begin{array}{l}\text { Favours treatment } \\
(\mathrm{SMD}-0.21,95 \% \mathrm{CI}- \\
0.40,-0.02, \mathrm{P}=0.03)\end{array}$ & $\begin{array}{l}\text { Favours treatment } \\
(\mathrm{SMD}-0.20,95 \% \mathrm{CI}- \\
0.39,-0.02, \mathrm{P}=0.03)\end{array}$ & N/A \\
\hline
\end{tabular}

Cholinesterase inhibitors for dementia with Lewy bodies, Parkinson's disease dementia and cognitive impairment in Parkinson's disease 32 (Review) 


\section{WHAT'S NEW}

Last assessed as up-to-date: 30 August 2011.

\begin{tabular}{lll}
\hline Date & Event & Description \\
\hline 30 August 2011 & Amended & $\begin{array}{l}\text { A pre-publication search was performed for this review on 30 August 2011 to ensure the review was } \\
\text { as up-to-date as possible before publication }\end{array}$ \\
\hline
\end{tabular}

\section{H I S T O R Y}

Protocol first published: Issue 2, 2007

Review first published: Issue 3, 2012

\begin{tabular}{|c|c|c|}
\hline Date & Event & Description \\
\hline 8 February 2007 & New citation required and conclusions have changed & Substantive amendment \\
\hline
\end{tabular}

\section{CONTRIBUTIONS OF AUTHORS}

MR extracted the data, did the analysis and wrote the current draft. CF and IM contributed to previous versions of the review and commented on the current draft. RM wrote the first draft of this new title, was responsible for design and contributed to data extraction, interpretation, analysis and redrafting.

\section{DECLARATIONS OF INTEREST}

$\mathrm{RMcS}$ has received financial support to attend conferences from Eisai, Shire and Novartis, all marketers of cholinesterase inhibitors, more than five years ago. Within the last two years, his institution has received funding for his activities as a local PL for a Novartis study of rivastigmine patch versus tablets in Parkinson's disease dementia.

\section{SOURCES OF SUPPORT}




\section{Internal sources}

- Oxfordshire and Buckinghamshire Mental Health Partnership NHS Trust, UK.

- Nuffield Department of Medicine, University of Oxford, UK.

\section{External sources}

- No sources of support supplied

\section{NDEX TERMS}

\section{Medical Subject Headings (MeSH)}

Cholinesterase Inhibitors [adverse effects; *therapeutic use]; Cognition Disorders [*drug therapy; etiology]; Dementia [*drug therapy; etiology]; Indans [adverse effects; therapeutic use]; Lewy Body Disease [*drug therapy]; Neuroprotective Agents [adverse effects; therapeutic use]; Parkinson Disease [ ${ }^{*}$ complications]; Phenylcarbamates [adverse effects; therapeutic use]; Piperidines [adverse effects; therapeutic use]; Randomized Controlled Trials as Topic

\section{MeSH check words}

Humans 